\title{
Var Adam ekki lengi í helvíti? Hafa stjórnunar- hættir á Íslandi breyst eftir hrunið 2008?
}

\author{
Ásta Dís Óladóttir og Gylfi Magnússon ${ }^{1}$
}

\begin{abstract}
Ágrip
Íslensk fyrirtæki fóru mikinn á árunum fyrir efnahagshrunið árið 2008 og fjárfestingar stjórnenda skiluðu Íslandi í efsta sæti á hinum alpjóðlega World Investment Report lista ár eftir ár. „Mig er farið að klæja í puttana að loka nýjum díl, við höfum ekkert gert á pessu ári," var eitt af peim svörum sem komu fram í rannsóknum höfunda fyrir hrunið enda fjárfestu íslenskir stjórnendur meira en aðrir og iðulega í stærri fyrirtækjum en peim sem peir störfuðu fyrir. Eignarhald á hlutabréfum í aðdraganda hruns einkenndist mjög af skuldsetningu hluthafanna. Mikil vogun varð til pess að eigendur skráðra félaga urðu afar viðkvæmir fyrir niðursveiflum á hlutabréfamarkaði enda veðjuðu peir djarft á öra hækkun. Pað pýddi jafnframt mikla pressu á stjórnendur sem urðu helst að skila sífellt glæsilegri niðurstöðum í ársfjórðungsuppgjörum til að stuðla að endalausri hækkun hlutabréfaverðs. Í greininni er skoðað hvort stjórnunarhættir hafi breyst í íslensku viðskiptalífi frá hruni. Rannsóknin náđi til 42 stjórnenda á lista yfir 300 stærstu fyrirtæki landsins. Voru peir m.a. spurðir hvort stjórnunaraðferðir peirra hefðu eitthvað breyst eftir hrunið 2008. Margar rannsóknir liggja fyrir um aðferðir og einkenni góðra stjórnenda og rannsóknir á aðferðum íslenskra stjórnenda á árunum fyrir hrun bentu til pess að peir væru áhættusæknir og fljótir að taka ákvarðanir. Sjálfstraustið var mikið, birtist jafnvel sem hvatvísi. Pá virtist skortur á langtímastefnumótun. Rannsóknarspurningin sem hér er sett fram er hvort aðferðir (stjórnunarhættir) íslenskra stjórnenda hafi breyst eftir efnahagshrunið árið 2008. Í ljós kom að stjórnendur í íslensku atvinnulífi eru sammála um að margt hafi breyst í stjórnunarháttum frá pví fyrir hrun, óttinn við mistök hafi verið alls ráðandi í atvinnulífinu fyrst eftir hrunið og um tíma dró úr áhættusækni stjórnenda. Tíu árum síðar séu hlutirnir að nálgast ört pað sem áður var, pótt hugsanlega sé aðeins meiri varkárni við ákvarðanatöku, meira regluverk og formfesta og meiri áætlanagerð en var. Skuldsetning virðist minni en var á árunum fyrir hrun, pó eru margir stjórnendur á pví að rúmum 10 árum eftir hrun sé allt að fara í svipað horf og pað var. Bægslaganginum sé pó núna að mestu haldið bak við tjöldin.
\end{abstract}

\section{Abstract}

Many Icelandic companies were aggressively managed in the years before the 2008 economic collapse, and their investments kept Iceland at the top of the World

1 Ásta Dís Óladóttir er lektor í Viðskiptafræðideild Háskóla Íslands. Netfang: astadis@hi.is. Gylfi Magnússon er dósent í Viðskiptafræðideild Háskóla Íslands. Netfang: gylfimag@hi.is.

This work is licensed under a Creative Commons Attribution 4.0 License. 
Investment Report year after year. “We haven't finalised a new deal this year; I am getting itchy fingers" was one of the responses observed in the authors' study before the economic collapse, as Icelandic managers invested more than others and often in larger companies than their own. Ownership of shares in the run-up to the economic collapse was characterised by shareholder leverage. Significant risks meant that owners of listed companies became extremely vulnerable to stock market downturns, as they boldly bet on a rapid increase. This also meant that there was great pressure on those in management, who were required to deliver impressive results in quarterly reports to contribute to an ever-increasing share price. This article investigates whether something has changed since the economic collapse for managers in the Icelandic business sector. The study covered managers in 100 of Iceland's largest companies. They were asked, amongst other things, whether their methods and the methods of other managers had changed at all since the 2008 economic collapse. There are many studies available on different management styles, methods and characteristics of good management. Studies on the characteristics of and methods employed by Icelandic management in the years before the economic collapse indicated that they had an appetite for risk and were quick to make decisions. Self-confidence was high and managers even appeared impulsive. There was also a lack of long-term policy formulation. This paper examines whether these symptoms are still present today or whether management methods have changed. The analysis shows that managers within the Icelandic business community agree that management methods have changed somewhat and that the fear of mistakes was greater in the business sector right after the economic collapse. Ten years later things are, however, rapidly returning to how they were, although there may be slightly more caution in decision-making, stricter regulations and formality and more planning than was the case before. Leverage is less than in the years before the economic collapse. However, many managers believe that just over 10 years after the economic collapse, everything is returning to how it was before. Today, however, questionable activity is largely kept behind the scenes.

JEL flokkun: M10; F21; G31

Lykilorð: Íslenskir stjórnendur; áhættusækni; stjórnunarhættir; 2007; hroki og ábyrgðarleysi.

Keywords: Icelandic managers; preference for risk; management strategies; hubris.

\section{A brief stay in purgatory? Management in Iceland before and after the crash of 2008}

\section{Inngangur}

Fjárfestingar íslenskra fyrirtækja voru pað umfangsmiklar á árunum fyrir hrun að Ísland leiddi World Investment Report listann ár eftir ár, allt fram til ársins 2008. Íslenskir fjárfestar og stjórnendur fjárfestu mikið og iðulega í stærri fyrirtækjum en peim sem peir störfuðu fyrir eða áttu. Með viljann að vopni og nægan aðgang að fjármagni voru tækifærin á hverju strái. Umsvif íslenskra fjárfesta erlendis vöktu athygli í fjármálageiranum og í fjölmiðlum, sérstaklega í Danmörku og á Bretlandi.

Tímabilið í aðdraganda hruns var iðulega kallað góðærið. Рað einkenndist m.a. af mjög örum hagvexti, mikilli lántöku bæði fyrirtækja og heimila og eignaverðsbólu sem birtist bæði á fasteignamarkaði og pó sérstaklega hlutabréfamarkaði. ${ }^{2}$ Eignaverðsbólan ýtti undir

2 Hagvöxtur (breyting vergrar landsframleiðslu að raunvirði) áranna 2004 til 2007 var að jafnaði 7,2\% á ári (Heimild: Hagstofa Íslands og útreikningar höfunda). Útlán innlánsstofnana til innlendra aðila ríflega sjö- 
áhættusækni íslenskra stjórnenda og var raunar einnig að nokkru leyti afleiðing hennar. Hækkun eignaverðs bjó til hagnað, a.m.k. á pappír, og hvatti til frekari eignakaupa sem hækkaði enn eignaverð. Skuldsett eignarhaldsfélög gátu skilað ævintýralegri ávöxtun eigin fjár á skömmum tíma. Pað bjó til fyrstu milljarðamæringana í Íslandssögunni hvern á fætur öðrum. Lykillinn að velgengni var auðvelt aðgengi að lánsfé og par skipti lykilmáli hverjir héldu um stjórnartaumana í bankakerfinu.

Markaður sem verðlaunaði pá áhættusæknustu bjó til jákvæða endurgjöf (e. positive feedback) fyrir áhættusækni og ýtti pannig undir hana. Pað var liður í pví að búa til jákvæðan spíral (e. positive spiral) par sem áhættusækni bjó til eignaverðshækkun og par með hagnað, og hagnaðurinn ýtti undir enn frekari áhættusækni og pannig koll af kolli (Fenzl og Pelzmann, 2012). Meðan lánsfé var aðgengilegt, ýmist búið til í bankakerfinu eða fengið að utan, hélt spírallinn áfram.

Um leið og aðgengi að lánsfé varð erfiðara stöðvaðist spírallinn og snerist við. Fyrstu merki pess voru auknar áhyggjur erlendra lánveitenda af íslensku bönkunum árið 2006. Pá hrikti í en jákvæði spírallinn hélt pó áfram fram á mitt ár 2007. Pá snerist hann við. Minsky stund íslenska hagkerfisins var runnin upp (Minsky, 1992).

Við tók öfugur spírall sem gekk enn hraðar. Lækkun á eignaverði leiddi til taps og lækkunar eigin fjár sem leiddi til svartsýni og fjárhagsörðugleika. Fjárfestar tróðust hver um annan pveran í leit að neyðarútgangi en komust hvergi. Skortur á erlendu lánsfé pýddi að engin leið var að breyta innlendum eignum í erlenda mynt til að greiða niður lán í slíkum myntum. Fyrir vikið bæði hríðlækkaði eignaverð í krónum og gengi krónunnar gagnvart erlendum myntum. Eigið fé sem hafði orðið til í jákvæða spíralnum gufaði upp enn hraðar en pað hafði myndast. Rúmu ári eftir að lækkunarhrinan hófst hrundi fjármálakerfið.

Eftir sat hnípin pjóð í vanda með hrunið fjármálakerfi, gjaldmiðil með litlu lífsmarki, haldið á floti með höftum, stóran hluta fyrirtækja landsins með ónýta efnahagsreikninga og fjármál heimila í uppnámi. Sagan af pví hvernig leyst var úr peirri flækju verður ekki rakin hér. Hrunið hafði mikil áhrif á samfélagið allt. Eftir hrun heyrðust mjög greinilega raddir sem kölluðu á nýtt gildismat, spillingu skyldi útrýmt, græðgin skyldi minnka, heiðarleiki skyldi verða ríkjandi í íslensku viðskiptalífi og pannig skyldi byggja traust upp að nýju, stjórnunarhættir skyldu breytast í atvinnulífinu. Haldinn var pjóðfundur árið 2009 par sem fjöldi fólks tók pátt og sett voru fram gildi sem fólk vildi sjá í íslensku viðskiptalífi. Gildin sem urðu fyrir valinu voru jafnrétti, virðing, heiðarleiki og réttlæti (Pjóðfundur, e.d.).

Margar rannsóknir liggja fyrir um aðferðir og einkenni góðra stjórnenda, en engin ein algild skilgreining liggur fyrir á pví hvað felst nákvæmlega í hugtakinu stjórnunarhættir, pær eru jafn misjafnar og pær eru margar en lýsa aðferðum stjórnenda við rekstur og stjórnun félaga. Hér er pví skoðað hvort aðferðir íslenskra stjórnenda (stjórnunarhættir), hafi breyst eftir efnahagshrunið árið 2008. Fyrst verður fjallað um hvað einkenndi tímabilið fyrir hrunið og hvernig stjórnunarhættir voru á peim tíma og hvað hafði mögulega áhrif á aðferðir stjórnenda. Pá er fjallað um „hugtakið 2007“ og fyrir hvað pað stendur í huga peirra stjórnenda sem tóku pátt í peirri rannsókn sem hér er greint frá. Loks eru helstu pemu sem komu fram í svörum stjórnenda sett fram, pá taka við umræður.

\section{2 Árin fyrir hrun}

\subsection{Aðdragandinn}

Iðnbyltingin, sem gerbreytti lífskjörum í nágrannalöndunum, kom seint til Íslands. Allt fram á tuttugustu öld var Ísland tiltölulega fámennt eyland í Norður-Atlantshafi og landsmenn lifðu nær eingöngu af fiskveiðum og landbúnaði og voru í hópi fátækustu pjóða

földuðust að krónutölu frá árslokum 2002 til september 2008, fóru úr 747 milljörðum í 5.396 milljarða, par af ríflega fimmfölduðust útlán til heimila (Heimild: Seðlabanki Íslands). Raunverð hlutabréfa í Kauphöll Íslands hækkaði um rúm 50\% á ári á hverju áranna 2003 til 2005 (Heimild: Kauphöll Íslands og útreikningar höfunda). 
Evrópu í upphafi aldarinnar. Íslenskt efnahagslíf vakti pví litla eftirtekt utan landsteinanna. Pótt fyrrnefnd útrás hafi aðeins breytt pví pá beindust ekki augu allra að Íslandi fyrr en prír stærstu bankar landsins hrundu allir í sömu vikunni, í október 2008. Samanlagðir efnahagsreikningar (e. balance sheet) bankanna á peim tíma voru um 182 milljarðar dollara. Рað gerir hrun peirra pað priðja stærsta í sögunni á eftir Lehman Brothers og Washington Mutual (Sigurjonsson og Mixa, 2011).

Hrun bankanna markaði endinn á sjö ára tímabili af fordæmislausum efnahagsvexti par sem bankarnir uxu úr pví að vera litlir viðskiptabankar yfir í alpjóðlega fjárfestingabanka með samanlagðan efnahagsreikning sem var nær tíföld verg landsframleiðsla (e. GDP) Íslands pegar mest varð. ${ }^{3}$ Pótt fjármálakrísan hafi verið alpjóðleg og leikið mörg lönd grátt varð ekkert annað land fyrir pví að nánast allt fjármálakerfi pess hrundi.

Fyrir hrunið leit allt vel út á pappírnum. Svo virtist sem landsmenn hefðu breytt lítilli eyju par sem áður snerist allt um fisk í efnahagslega paradís. Fjöldi lítilla íslenskra fyrirtækja breiddi út vængi sína og reyndi fyrir sér á alpjóðamarkaði. Bankarnir voru fljótir að taka við sér og fullnýttu tækifærið í lánastarfsemi sem studdi við pessa útrás og jafnframt jók peirra eigin starfsemi á alpjóðavísu. Frumkvöðlaandi var mikill á Íslandi á pessum tíma eins og tíðkast hefur á Íslandi í gegnum tíðina en frelsisvæðingin og einkavæðing bankanna gaf af sér nýja tegund af frumkvöðlastarfsemi og áhættusækni (Sigurjonsson, 2010). Skýr merki voru um meiri áhættusækni Íslendinga en t.d. nágranna peirra annars staðar á Norðurlöndum á bóluárunum (Mixa og Vaiman, 2015).

Petta má til dæmis greina á kaupum Íslendinga á erlendum fyrirtækjum á árunum fyrir hrunið, sem virðast um margt lík viðureign Davíðs við Golíat, par sem lítil íslensk fyrirtæki í örum vexti yfirtóku sum hver mun stærri erlend fyrirtæki. Ein birtingarmynd pessa er að árið 2005 komu um 75\% tekna fyrirtækja í íslensku kauphöllinni erlendis frá. Jafnframt jókst flæði beinna erlendra fjárfestinga milli áranna 1997 og 2005 úr 5,2 milljörðum íslenskra króna í tæplega 442,2 milljarða (Seðlabanki Íslands, 2006). Petta er nærri 85-föld aukning á aðeins 7 árum og fá fyrirtæki sem stóðu að baki pessum fjárfestingum (Ásta Dís Óladóttir, 2009).

Ásta Dís Óladóttir (2006) rannsakaði á pessum tíma yfirtökur íslenskra fyrirtækja erlendis og gerði vegna pess könnun í ársbyrjun 2006. Tæplega 500 stjórnendur á Íslandi tóku pátt í könnuninni. Nokkrar spurningar voru lagðar fyrir stjórnendurna. Fyrst var spurt hvar fyrirtækin störfuðu og pá kom í ljós að einungis 57 fyrirtæki af 497 höfðu tekið pað skref að fjárfesta erlendis. Af pessum 57 fyrirtækjum störfuðu 38 í fleiru en einu landi og langflest fyrirtækin höfðu starfsemi í Bretlandi og Danmörku.

Pegar stjórnendur voru spurðir hvort peir hefðu keypt ráðandi hlut í fyrirtæki erlendis á sl. 12 mánuðum, eða á árinu 2005, kom í ljós að pað voru aðeins tæp 4\% sem höfðu lagt í slíkar fjárfestingar. Petta sýnir að tiltölulega fá fyrirtæki voru að fjárfesta í öđrum löndum en pau fjárfestu hins vegar mörg fyrir umtalsverðar fjárhæðir.

Pegar litið er til pess hvað einkenndi fjárfestingar stjórnenda á pessum tíma má sjá prjú atriði sem stóðu upp úr. Рað er sem á ensku nefnist „3 s“ (á íslensku „uhs“); Umfang (scope); Hraði (speed) og Sérhæfni (specificity). Umfang íslensku fyrirtækjanna var mikið. Íslensku fyrirtækin fylgdu fjárfestingarstefnu sem gerði peim kleift að stækka umtalsvert með einstaka fjárfestingum. Stjórnendur fyrirtækjanna fjárfestu í pekktum, vel reknum fyrirtækjum með breiðan og tryggan hóp viðskiptavina. Annað einkenni er hraði í fjárfestingum. Íslenskir fyrirtækjastjórnendur sýndu að peir töldu ekki eftir neinu að bíða pegar

3 Síðasta mæling á stærð bankakerfisins fyrir hrun miðaði við lok september 2008. Pá töldust heildareignir kerfisins 15.086 milljarðar króna (heimild: Seðlabanki Íslands) og höfðu aukist mjög ört mánuðina á undan vegna lækkunar gengis krónunnar. Verg landsframleiðsla árið 2008 var 1.575 milljarðar króna (heimild: Hagstofa Íslands) og samsvaraði pví bókfært verðmæti eigna bankakerfisins 9,6 faldri landsframleiðslu. Рað er pó rétt að hafa í huga að áður en gengi krónunnar tók að gefa verulega eftir í aðdraganda hruns var hlutfallið talsvert lægra. Pannig voru eignir bankakerfisins að jafnaði 7.589 milljarðar árið 2007 (heimild: Seðlabanki Íslands) og verg landsframleiðsla pess árs 1.378 milljarðar (heimild: Hagstofa Íslands). Hlutfallið par á milli er 5,5. Sú tala gefur líklega betri mynd af stærð bankakerfisins fyrir hrun. 
fyrirtækjakaup voru annars vegar. Kaupin tóku iðulega mjög stuttan tíma og stjórnendur afar fljótir að taka ákvarðanir (Ásta Dís Óladóttir, 2006). Petta rímar ágætlega við rannsókn Inga Rúnars Eðvarðssonar og Guðmundar Kristjáns Óskarssonar (2009) par sem kom í ljós að helstu einkenni íslensku fyrirtækjanna á árunum fyrir hrun voru hröð ákvarðanataka og stutt stjórnunarspönn.

Priðja og síðasta atriðið er sérhæfing, en svo virðist sem sum íslensku fyrirtækin hafi fylgt stefnu sem gerði peim kleift að verða leiðandi á sínu sviði í heiminum. Mörg íslensku fyrirtækjanna störfuðu á mjög sérhæfðum markaðssyllum sem gerði peim kleift að verða fremst í sínum flokki (Ásta Dís Óladóttir, 2009).

\subsection{Viðskiptalíkanið}

Upphaf pess sem stundum hefur verið kallað „,viðskiptalíkan góðærisins” má í raun rekja til pess að verðmat fyrirtækja í lok niðursveiflunnar sem endaði seinnihluta árs 2002 var mjög lágt. ${ }^{4}$ Рað var umtalsvert af peningum í umferð sem m.a. mátti rekja til aðgerða Seðlabankans. Innlánsvextir Seðlabankans fóru lækkandi úr 6,9\% um áramótin 2000/2001 í 2,8\% snemma árs 2003. Aukinn aðgangur að ódýru erlendu fjármagni, einkum fyrir milligöngu bankanna, skipti pó ekki síður máli.

Komið var að kynslóðaskiptum í mörgum fyrirtækjum sem voru fjölskyldufyrirtæki og eigendur peirra voru að setjast í helgan stein eða höfðu ekki fjárhagslega burði til pess að greiða öðrum út. Viðskiptalíkanið gekk pannig út á pað að kaupa fyrirtæki sem voru í sæmilegum rekstri á lágum EBITDA (e. earnings before interest, taxes, depreciation and amortization, rekstrarhagnaður) margföldurum. Í kjölfarið var svo mörgum félögum skipt upp í fasteignafélög annars vegar og rekstrarfélög hins vegar. Petta nýttu íslensku bankarnir sér og mikill gróði myndaðist til að byrja með.

Bankarnir fundu fjárfestingatækifæri, lánuðu í yfirtökuna og fóru með fyrirtækin á markað (Jakob Bjarnason, munnleg heimild 10. janúar 2009; Magnús Sveinn Helgason, 2010, einkum hluti III). Krosstengslin voru allsráđandi (Margrét V. Bjarnadóttir og Guðmundur Axel Hansen, 2010; Páll Hreinsson, Sigríður Benediktsdóttir og Tryggvi Gunnarsson, 2010, kaflar 8.7 og 8.12). Pá tóku bankarnir seljendur í einkabankapjónustu og högnuðust á öllum skrefunum. Ef eigendur fyrirtækjanna seldu pau, pá fengu bankarnir söluandvirðið iðulega til sín, sem innlán eða í eignastýringu.

Aukin eftirspurn eftir fyrirtækjum pýddi að EBITDA margfaldarinn fór hækkandi. Far¡ð var í samruna, yfirtökur, ýmiss konar hagræðingar og fleira. Eignarhaldið varð flóknara og vogaðra. Раð voru stofnuð skuldsett eignarhaldsfélög og rekstrarfélögin svo endurfjármögnuð. Vogunin jókst með hverju prepi. Hækkandi eignaverð bjó til eigið fé í eignarhaldsfélögunum og pá myndaðist tækifæri til pess að lána peim til viðbótar til að fjárfesta í öðrum félögum.

Fyrirtækin sem voru yfirtekin voru sum hver sett á markað en farið með önnur í yfirtöku á Íslandi eða erlendis. Nánast undantekningalaust var um skuldsettar yfirtökur að ræða, p.e. ekkert nýtt eigið fé var sett inn í félagið og ef pað var gert var pað ansi oft lánað inn í upphaflega eignarhaldsfélagið eða inn í fyrsta rekstrarfélagið (Jakob Bjarnason, munnleg heimild 10. janúar 2009). Í skýrslu Rannsóknarnefndar Alpingis (Páll Hreinsson, Sigríður Benediktsdóttir og Tryggvi Gunnarsson, 2010, 2. bindi bls. 94) kemur fram „Eftir pví sem leið frá aldamótum jókst vægi fjárfestingarbankastarfsemi islensku bankanna. Detta pýddi að vægi íslenskra rekstrarfyrirtækja minnkaði verulega i lánasöfnum bankanna. [...] [S]mám saman uxu lán til eignarhaldsfélaga og erlendra félaga og á árinu 2007 urđu lán til pessara aðila meira

4 Raunverð hlutabréfa í Kauphöll Íslands lækkaði um pví sem næst 20\% á ári bæði árin 2000 og 2001. Að hluta til var petta í samræmi við alpjóðlega próun, pví að illa áraði á alpjóðamörkuðum vegna endaloka netbólunnar svokölluðu. Að hluta átti petta sér séríslenskar skýringar sem ekki verður reynt að rekja hér. Íslenska krónan átti einnig erfitt uppdráttar á pessum tíma sem endaði með pví að Seðlabanki Íslands gafst upp á gengismarkmiði sínu og skipti yfir í verðbólgumarkmið árið 2001. Krónan féll töluvert vegna pessa pótt hún næði sér reyndar aftur á strik árin á eftir. Verð innlendra hlutabréfa féll fyrir vikið enn meira í erlendri mynt en í krónum. 
en helmingur allra lána til viðskiptavina.“ Jafnframt segir (sama heimild, bls. 95) „Hin mikla hlutdeild eignarhaldsfélaga er athyglisverð. Lán til eignarhaldsfélaga eru ekki tryggð með traustum rekstri heldur eru verðbréf uppistaðan i eignum peirra, oft hlutabréf. Líta má svo á að lán til eignarhaldsfélags, sem á hlutabréf í tilteknu hlutafélagi, sé svipað víkjandi láni til hlutafélagsins."

Pegar íslensku bankarnir stækkuðu pá fluttu peir petta viðskiptalíkan til erlendra starfsstöðva sinna og héldu áfram. Rekstrarlíkanið var alls staðar áhættusækið og póknanadrifið. Á meðan eignaverð fór hækkandi varð til hagnaður á öllum prepum og bankarnir og eigendur peirra högnuðust umtalsvert (Jakob Bjarnason, munnleg heimild 10. janúar 2009). ${ }^{5}$ Vandamálið var að ef einn hlekkurinn í slíkri keðju myndi gefa sig, pá myndi pað hafa áhrif á aðra líka og afleiðingarnar gætu orðið afar alvarlegar (Sigurjonsson og Mixa, 2011). Hin mikla vogun fjölmargra efnahagsreikninga ýkti áhrif bæði upp- og niðursveiflna í eignaverði á afkomu og eigið fé.

\section{3 Áhættusækni}

Ísland er með eitt smæsta hagkerfi í heimi og pað minnsta innan OECD ríkjanna. Fyrstu árin eftir síðustu aldamót voru íslensk fyrirtæki/fjárfestar mjög öflugir erlendis. Árið 2005 fjárfesti Ísland 60\% af vergri landsframleiðslu erlendis. Pað var hærra hlutfall en hjá nokkru öðru ríki innan OECD (Halla Tómasdóttir og fl., 2007).

Pessar fjárfestingar voru undantekningalítið djarfar. Pví er ljóst að talsverð áhætta hefur verið tekin í viðskiptalífinu. Áhættu má skilgreina sem möguleikann á pví að missa eitthvað eða tapa einhverju og hún getur verið margs konar. Stjórnendur taka áhættu í rekstri, fjárfestar taka áhættu við kaup á bréfum eða í gegnum aðrar fjárfestingar. Áhætta getur falist í pví að viðkomandi velur á milli mögulegra kosta par sem mismunandi líkur eru á væntum ávinningi (Meyer og Meyer, 2005).

Sanders og Hambruck (2007) skilgreindu áhættu (e. risk) við fjárfestingu með peim hætti að hún samanstandi í raun af premur páttum, p.e. stærð fjárfestingarinnar, hversu langt sé á milli bestu og verstu hugsanlegrar niðurstöðu fjárfestingarinnar og hversu miklar líkur eru á stórtapi. Peir telja að pessi prjú atriði hafi áhrif á áhættusækni einstaklinga. Áhættusækni felst í pví að einstaklingur velur áhættu umfram öryggi. Áhættusækni getur átt sér ýmsar skýringar og hefur áhrif á stjórnunarhætti. Kaupréttarsamningar stjórnenda ýttu undir áhættutöku í viðskiptalífinu á árunum fyrir hrun. Sú próun sem orðið hafði á árunum fyrir hrun par sem kaupréttarsamningar voru notaðir í miklum mæli var mjög umdeild og ýtti undir áhættusækni meðal stjórnenda (Bebchuk og Fried, 2004). Sanders og Hambruck (2007) könnuðu hvort áhættusækni stjórnenda myndi aukast væru valréttarsamningar notaðir og skoðuðu peir stjórnendur hjá um 800 bandaríkum fyrirtækjum á árunum 1994-2000.

Birtingarmynd áhættusækni í fjármálageiranum er áberandi við greiningu á viðhorfi og skoðunum stjórnenda. Peir sem teljast áhættusæknir hafa oft skekkt viðhorf til peninga og eigna, eru háðir spennunni og nota fé annarra eða taka lán til að fjármagna næsta leik (Wong og Carducci, 1991). Samkvæmt Kristínu Loftsdóttur og Helgu Björnsdóttur (2015) var hamagangurinn fyrir hrun svo mikill að samkeppni snerist upp í að menn kepptust um að vera harðasti naglinn á markaðinum og svifust einskis við að svíkja, blekkja og brjóta sem flestar reglur.

Áhættusækið fólk tekur oft óraunhæfar og fjárhagslega skaðandi ákvarðanir án pess að reikna dæmið til enda. Рað lætur leiðast af tilfinningarlegum toga eða svokölluðu lottóhugarfari. Pá stjórnast áhættusækið fólk ekki síður af hinu sér íslenska viðhorfi um að „petta reddast“ (Hrafnhildur M. Eyjólfsdóttir og Smith, 1996) Velgengni er oft aðal drifkrafturinn að baki áhættusækni (Kristín Loftsdóttir og Helga Björnsdóttir, 2015). Í tillögu til pingsályktunar um breytingu á IX. viðauka (Fjármálapjónusta) við EES-samninginn sem lögð var fyrir Alpingi á 140. löggjafarpingi 2011-2012 kemur fram að:

5 Samanlagður hagnaður íslenskra viðskiptabanka árin 2002 til 2007 var skv. uppgjörum peirra 612 milljarðar króna. Hagnaðurinn jókst mjög hratt allt til ársins 2006 og var nær 27 sinnum meiri pað ár en árið 2002. Heimild: FME og útreikningar höfunda. 


\begin{abstract}
Mikil og óhyggileg áhættusækni í bankageiranum leiddi til falls einstakra fjármálastofnana og kerfislægra vandamála í aðildarríkjum og á alpjóðavettvangi. Ástæður slíkrar áhættusækni eru margar og flóknar, en yfirvöld og eftirlitsstofnanir, p.m.t. G-20 og evrópska bankaeftirlitsnefndin (CEBS), eru sammála um að óheppilegt fyrirkomulag starfskjara sumra fjármálastofnana hafi verið áhrifapáttur. Starfskjarastefna sem hvetur til áhættutöku, sem er umfram almennt áhættupol stofnunar, getur grafið undan traustri og skilvirkri áhættustýringu og aukið á óhóflega áhættusækni. Pess vegna eru alpjóðlega sampykktu og staðfestu meginreglur ráðgjafanefndarinnar um fjármálastöðugleika (FSB) um góðar póknunarvenjur sérstaklega mikilvægar.
\end{abstract}

Jóhanna Sigurðardóttir, páverandi forsætisráðherra Íslands, sagði á 138. löggjafarpingi (6. október 2009) „,Tíma ofurlauna og kaupauka fyrir stjórnlausa áhættusækni er lokid“. Hún sagði jafnframt að ákvarðanir stjórnenda, stjórnarfólks og hluthafa á árunum fyrir hrunið, ,,ekki síst óhófleg áhættusækni, voru grundvöllur ofpenslu og síðar hruns bankanna".

Eftir pví sem lengra hefur liðið frá hruni hefur umræða um áhættusækni í íslensku viðskiptalífi vaxið á ný. Árið 2018 taldi Már Guðmundsson páverandi bankastjóri Seðlabanka Íslands vísbendingar um að áhættusækni væri að vaxa í íslensku bankakerfi og eftirlitsaðilar purfi að sjá til pess að hún gangi ekki of langt. (Seðlabanki Íslands, 2018, bls. 3)

Fyrirtækjasamsteypur og eignarhaldsfélög sem byggja á verulegri skuldsetningu og treysta á hækkun eignaverðs til að búa til hagnað og eigið fé eru mjög viðkvæmar fyrir niðursveiflum í eignaverði. Slíkar einingar falla vel að kenningum Minsky (1992) um „Ponzi lántakendur". ${ }^{6}$ Pá nægir fjárstreymi frá rekstri ekki til að standa í skilum við lánveitendur á vöxtum og afborgunum heldur parf einnig að koma til sífelld hækkun eignaverðs. Hún er svo ýmist innleyst og pannig gert upp við lánveitendur eða aukin lán tekin út á hærra eignaverð og hagnað sem hefur orðið til á pappír.

Við pessar aðstæður verður mjög brýnt frá sjónarhóli fjárfesta að stjórnendur fyrirtækja sýni sífellt betri árangur, á pappír, pví að annars er hætt við að eignaverð hætti að hækka eða jafnvel taki að lækka og spilaborgin hrynji. Sérstaklega er mikilvægt að verð mælist hátt á uppgjörstíma, oftast um ársfjórðungamót, pví að pá er staðan tekin og eigið fé og hagnaður reiknaður út. Vísbendingar voru komnar fram fyrir hrun um að óeðlilegar hækkanir hefðu orðið á verði hlutabréfa í Kauphöll Íslands síðustu daga hvers ársfjórðungs, sem síðan gengu til baka í upphafi næsta ársfjórðungs (Gylfi Magnússon, 2006). Frekari skýringar á pví mynstri komu svo fram eftir hrun pegar sýnt var í dómsmálum fram á kerfisbundna markaðsmisnotkun íslenskra banka í aðdraganda hruns par sem leitast var við að halda hlutabréfaverði óeðlilega háu.

Pessi uppbygging á íslenskum fyrirtækjasamsteypum fyrir hrun getur án efa skýrt að einhverju marki áhættusækni stjórnenda fyrirtækjanna. Peim var nauðugur einn kostur að vaxa hratt og ná fram hækkun á hlutabréfaverði, annars hefði viðskiptalíkanið ekki gengið upp.

\title{
2.4 Stjórnendur, aðferðir og einkenni
}

Engin ein almenn skilgreining liggur fyrir á hugtakinu stjórnunarhættir, heldur lýsa peir pví hvernig stjórnendur stýra félögum og hvaða aðferðum peir beita í mismunandi umhverfi. Rannsakendur innan stjórnunar- og leiðtogafræða benda á að pað fari eftir aðstæðum í samfélaginu hverju sinni hvaða kröfur séu gerðar til stjórnenda, enda sé forysta skilgreind á einstaklingsbundinn hátt (Yukl, 2013). İ rannsókn Stogdill (1948) kom fram að persónuleg einkenni líkt og aðlögunarhæfni einstaklingsins, næmni fyrir umhverfinu, metnaðargirni, vilji einstaklingsins til að ná árangri, að geta unnið náið með öðrum, stað-

6 Stefán Ólafsson (2016) telur að íslenska hrunið megi að nokkru marki skýra með kenningum Minsky. 
festa, atorkusemi, viljinn til pess að axla ábyrgð og getan og viljinn til að hafa áhrif á aðra hefði áhrif á stjórnunarhætti.

Pá setti Stogdill fram (1974) að eiginleikar góðs leiðtoga og stjórnenda séu að viðkomandi sé ákveðinn í að ná markmiðum sínum, hefur sjálfstraust og hæfileika til pess að hafa áhrif á aðra. Pá skiptir sjálfsálit máli, að einstaklingar hafi gott álit á sjálfum sér og getu sinni sem stjórnanda. Pannig telji stjórnandi sem hefur mikið sjálfsálit, sig vera bæði verðugan og hæfan til að takast á við flest pau verkefni sem reka á fjörur hans. Petta getur að mati Jones (2013) komið stjórnendum nokkuð langt í starfi og eykur getu peirra til að takast á við mikilvægar og erfiðar ákvarðanir, en getur líka snúist upp í andhverfu sína og orðið stjórnendum að falli. Í tveimur rannsóknum á sjálfstrausti sérfræðinga á íslenskum fjármálamarkaði fyrir hrun kom fram að peir hefðu, líkt og starfssystkini peirra í öðrum löndum, almennt of mikla trú á eigin getu, m.a. til að sjá fyrir próun markaða (Haukur Freyr Gylfason, Friðrik H. Jónsson og Haukur C. Benediktsson, 2006 og 2007).

pá eru engir tveir einstaklingar eins, persónueinkenni einstaklinga eru mismunandi. Pannig mótast stjórnunarhættir af persónuleika einstaklingsins og menntun hans, pví umhverfi sem hann starfar í og menningu fyrirtækisins sem hann starfar hjá (Armstrong, 2006). Pá hefur persónuleikinn áhrif á hvernig stjórnendur bregðast við aðstæðum hverju sinni. Pættir eins og samviskusemi, jákvæðni, neikvæðni, hversu samvinnubýður viðkomandi einstaklingur er og opinn fyrir nýjungum felast í persónueinkennunum (Jones, 2013).

En stjórnunarhættir og forysta snúa að miklu leyti um sjálfspekkingu og pað að trúa á sjálfan sig sem stjórnanda, pekkja eigin styrkleika og veikleika og hafa góða sjálfsstjórn (Coleman og Early, 2005). Einstaklingar með góða sjálfsmynd eru jafnan með gott sjálfstraust og láta áreiti ekki hafa mikil áhrif á sig. Pannig fara einstaklingar með jákvætt viðhorf gjarnan að reglum og bera virðingu fyrir verklagi á meðan peir sem eru með neikvætt viðhorf brjóta oftar reglur og verklag. Hæfileikinn til pess að hafa stjórn á hvötum sínum, halda einbeitingu, fylgja áætlunum og fara eftir ferlum er mikilvægur í pessu samhengi. Pá heldur Daft (1998) pví fram að góðir stjórnendur láti sig aðra varða og taki hagsmuni heildarinnar fram yfir eigin hagsmuni, peir taki skipulagsheildina fram yfir persónulegar parfir, pví skipta aðferðir stjórnanda miklu máli.

Í fyrirtækjarekstri er mikilvægt að hafa hæfileika til pess að greina umhverfið rétt og taka raunhæfar og skynsamlegar ákvarðanir. Ýmislegt getur haft áhrif á og skekkt ákvarðanatöku eins og t.d. of mikið sjálfsálit líkt og áður hefur verið bent á, of mikil bjartsýni, að gefa sér niðurstöður fyrirfram, pressa, persónuleg reynsla og meðfæddir gallar í rökhugsun einstaklinga (Mintzberg og Gosling, 2002).

Rannsókn Ho, Huang, Lin og Yen (2016) sýndi að bankastjórar með of mikið sjálfstraust voru líklegri en aðrir til að draga úr kröfum til lántaka og auka vogun í aðdraganda fjármálakrísunnar. Viðkomandi bankar voru fyrir vikið viðkvæmari fyrir niðursveiflu og líklegir til að lenda í kröggum.

Árangur fyrirtækja er oft rakinn til stjórnenda og pví vekja peir oft mikla athygli. Viðurkenningar á borð við val á „,Viðskiptamanni ársins“ og „Manni ársins í íslensku viðskiptalífi“ eru dæmi um petta. Sambærilegar viðurkenningar má finna erlendis. Ekki er pó auðvelt að benda nákvæmlega á hvað pað er sem veldur pví að tilteknir einstaklingar eru valdir eða hvað gerir stjórnendur í viðskiptalífinu að áhrifamiklum leiðtogum. Pó virðist sem svo að pað að hvetja aðra til góðra verka, að vekja eldmóð meðal peirra sem fylgja viðkomandi og fá alla til að stefna að sameiginlegri sýn séu peir stjórnunarhættir sem fá aðra til að fylgja peim (Ciulla, 2005; Northouse, 2016).

\subsection{1 Íslenskir stjórnendur}

Sérkenni íslenskra stjórnenda hafa verið skoðuð og greind í ýmsum rannsóknum. Hrafnhildur M. Eyjólfsdóttir og Smith (1996) telja að lega landsins, einangrun, óstöðugleiki í umhverfinu og efnahagslegt óöryggi hafi sýnt Íslendingum fram á hve mikils virði pað 
er að starfa saman í sátt og samlyndi. Íslendingar treysti almennt lítið á formlegar reglur vegna pess að peir sjá enga ástæðu fyrir slíkum hindrunum og líður vel í óvissuástandi. Pví telja pær að íslenskir stjórnendur falli oft í pá gryfju að vera of bjartsýnir og að peir eigi pað til að göslast áfram undir gunnfána hugtaksins „,petta reddast“.

Sigrún Davíðsdóttir (2006) skoðaði hvað einkennir Íslendinga í viðskiptum. Par kom fram að ákvarðanataka sé hröð, peir hefðu mikla hæfileika til pess að leysa ýmis vandamál, byggju yfir eldmóði og hefðu einlægan áhuga á viðfangsefni sínu.

Til að átta sig á aðferðum íslenskra stjórnenda á árunum fyrir efnahagshrunið parf að hafa hliðsjón af pví hvaða fyrirtækjum peir voru að stjórna. Á árunum fyrir hrun fór mikið fyrir áðurnefndum útrásarfyrirtækjum og í alpjóðlegum samanburði voru íslensku útrásarfyrirtækin frekar lítil. Aðferðir stjórnenda endurspegla að fyrirtækin voru smá og lítil áhersla á formlegheit. Milliliðalaus samskipti óháð stöðu í skipuriti voru viðtekin venja.

Erlendir aðilar sem áttu í viðskiptum við íslenska stjórnendur lýstu peim á pann hátt að peir hefðu einkenni frumkvöðla, væru vel menntaðir, athafnasamir, hugmyndaríkir, viljugir til að læra og próast, fúsir til pess að dreifa ábyrgð, viljugir til að stækka fyrirtæki sín og tilbúnir til pess að taka umtalsverða áhættu (Ásta Dís Óladóttir, 2009).

Niðurstöður Inga Rúnars Eðvarðssonar og Guðmundar Kristjáns Óskarssonar (2009) benda til pess að íslenskir stjórnendur beiti gjarnan ólíkum aðferðum við stjórnun og sér í lagi lýðræðislegum stjórnunaraðferðum sem felast í liðsstarfi. Pá kom fram að mismunandi aðferðum er beitt eftir pví hvort stjórnendur voru með háskólamenntun eða ekki og að konur stjórni öðruvísi en karlar.

Dögg Gunnarsdóttir (2007) gerði rannsókn á íslenskum stjórnendum par sem í ljós kom að í samanburði við önnur lönd væru starfsmenn mjög snemma gerðir að stjórnendum. Pannig voru íslenskir stjórnendur skilgreindir sem óformlegir og töldust umbreytingaleiðtogar. Íslenskir stjórnendur póttu vera djarfari og hugsa meira hnattrænt í sókn sinni en margir stjórnendur í stórfyrirtækjum í öðrum löndum. Pegar íslensk útrásarfyrirtæki voru skoðuð sérstaklega kom í ljós að pau atriði sem einkenndu stjórnunarhætti voru áhrif menningar á stjórnunarstílinn, stéttleysið, lárétt skipulag fyrirtækja, lágur aldur stjórnenda, áhættusækni, óformleg samskiptahefð og „reddaragenið.“

Árin eftir hrun ríkti mikil óvissa og íslenskir stjórnendur virtust hafa tileinkað sér breytta stjórnunarhætti. Í pví fólst einkum að frekar var ráðist í langtímastefnumótun sem og að áætlanir um skilvirka, gagnsæja stjórnunarhætti lágu frekar fyrir (Ingi Rúnar Eðvarðsson og Guðmundur Kristján Óskarsson, 2009). Ekki var um einhverja eina tegund nýrra stjórnunarhátta að ræða heldur virtist hver stjórnandi purfa að finna pá aðferð til stjórnunar sem viðkomandi taldi henta sínu fyrirtæki og starfsemi sem best. Urðu stjórnendur að vera sífellt á tánum til að halda í við pær kröfur sem gerðar voru á pessum tíma (Porkell Sigurlaugsson, 2009).

\section{5 Árið 2007}

„,Petta er svo mikið 2007“ hefur fest sig í sessi og er stundum notað pegar fólk sér pað sem pví finnast táknmyndir græðgi og spillingar í íslensku samfélagi, eitthvað sem pykir óhóflegt eða yfirborðskennt. Pannig er ártalið 2007 og pað sem gerðist á árunum fyrir hrun orðið að hugtaki (Guðni Tómasson, 2017). Ártalið 2007 er notað yfir ákveðinn lífsstíl fólks en hann pótti einkennast af miklum lúxus. Aðgangur almennings að lánsfé og aukinn kaupmáttur birtist til að mynda í pví að árið 2007 voru seldir fleiri Range Rover jeppar hér á landi en í Svípjóð og Danmörku til samans og ýmsar aðrar sölutölur voru hærri hér á landi en annars staðar, til að mynda á Bang \& Olufsen, sem meira var selt af hér á landi en í Moskvu.

Pá voru framkvæmdir miklar á pessum tíma og tugpúsundir iðn- og verkamanna komu til landsins til að styðja við pá miklu uppbyggingu sem hér var. ${ }^{7}$ Pví má segja að Ísland

7 Á premur mestu uppgangsárunum fyrir hrun, 2005 til 2007, fluttu 14.576 erlendir ríkisborgarar til landsins 
hafi breyst frá frekar einsleitu samfélagi og orðið fjölmenningarsamfélag á afar skömmum tíma, en með aðild að EES opnuðust tækifæri fyrir vinnuafl frá Evrópu (Eiríkur Bergmann, 2014; Magnússon o.fl., 2018). Byggingarkranar póttu táknmynd ársins 2007, en pá mátti sjá hvert sem litið var.

Boðsferðir fyrirtækja voru nánast daglegt brauð á pessum tíma, hvort heldur í laxveiði á Íslandi, fótboltaferðir í Bretlandi eða veislur í Mónakó par sem snekkjur voru fundastaðir og kampavínið flæddi. Gunnar Hersveinn (2013) hefur petta að segja um tímabilið fram að efnahagshruninu ,Tíðarandi græðgi, taumleysi, óbilandi bjartsýni og gildislausar hegðunar hafði ríkt um skeið. Skefjalaus heimskan fékk verðlaun, viðurkenningar og himinhá bankalán. Græðgin, agaleysið, framsæknin og hrokinn áttu greiðan aðgang að völdum, pjóðareignum og bankalánum en forsjálni, heiðarleiki, jöfnuður, umhyggja, ábyrgð og nægjusemi komu að luktum dyrum".

Hegðun fjárfesta endurspeglaðist að hluta til í samfélaginu almennt. Aukinn aðgangur að lánsfé og aukinn kaupmáttur fólks ýtti enn frekar undir pá pætti sem oft eru kenndir við árið 2007, eyðslu um efni fram.

Kenningar Robert Shiller $(2017,2019)$ um hagfræði frásagnar (e. narrative economics) geta skýrt að nokkru marki áhættusækni og órökrétta ofsakæti (e. irrational exuberance) bóluáranna. Umræðan á peim tíma, í fjölmiðlum og manna á meðal, um fjármálasnillinga og ósigrandi útrásarvíkinga, ofsagróða og nýjan grundvöll hagkerfisins o.fl. ýtti undir sjálfstraust og áhættusækni og bjó til væntingar um áframhaldandi vöxt eignaverðs og hagnaðar. Pannig mótaði umræðan hegðun manna sem hafði áhrif á próun hagkerfisins sem svo aftur hafði áhrif á umræðuna.

Pá einkenndist menning margra fyrirtækja fyrir hrun af of mikilli áhættusækni, takmarkaðri yfirsýn stjórnar og ofuráherslu á hagnað sem dreifðist á fáa aðila. Hjarðhegðun viðgekkst í stjórnum margra fyrirtækja, pegar stjórnarmenn hefðu átt að vera sjálfstæðir og beita gagnrýnni hugsun við ákvarðanatöku (Guðrún Finnborg Pórðardóttir og Hrafnhildur Mooney, 2016).

\subsection{Eftirhrunsárin}

Fjölmargir Íslendingar lentu í miklum erfiðleikum eftir efnahagshrunið og gerðu hvað peir gátu til að halda sér á floti. Pá má halda pví fram að margir hafi jarðtengst að nýju, komist nær rótunum ef svo má segja. Umræðan gerbreyttist. Enginn talaði lengur um fjármálasnillinga og vöxt hagnaðar. I pess stað var rætt um skuldavanda heimila og fyrirtækja, glannaskap fyrri ára og meinta sökudólga. Sjávarútvegurinn náði vinsældum að nýju enda skapaði veik króna mun meiri útflutningstekjur en áður. Meiru munaði pó um vöxt ferðapjónustunnar hvort sem pað er nú eldgosinu í Eyjafjallajökli árið 2010 að pakka eða einhverju öðru. Ferðapjónusta fór á mikla siglingu í kjölfar pess og bjó bæði til fjölda starfa og gjaldeyri. ${ }^{8}$ Heildarfjöldi ferðamanna sem kom til Íslands var 566 pús. árið 2011 en 2.225 pús. sex árum síðar (Ferðamálastofa, 2019). Slík aukning hafði róttæk áhrif á íslenskt atvinnulíf, styrkti krónuna til muna, bjó til fjölda starfa og miklar tekjur fyrir bæði fyrirtæki og hið opinbera. Báðar pessar atvinnugreinar ýttu svo undir sprota- og nýsköpunarstarfsemi og má segja að staðan hafi sjaldan eða aldrei verið betri hvað pað varðar í sjávarútvegi (Ásta Dís Olladóttir, 2019; Ásgeir Jónsson, 2015; Sigurður Már Jónsson, 2014)

Lykilspurningin í pessari rannsókn snýr að pví hvort stjórnunarhættir íslenskra stjórnenda hafi breyst eftir efnahagshrunið. Til að átta sig á pví parf einnig að skoða umgjörðina. Hin svonefnda endurreisn efnahagslífsins hefur í raun gengið vonum framar, sérstaklega

umfram pá sem fluttu frá landinu. Pað var pá langstærsta bylgja slíkra innflytjenda frá pví mælingar hófust. Við hrunið kom bakslag og um hríð fluttu fleiri frá landinu en til pess en undanfarin ár hefur innflytjendum fjölgað á ný og metið frá 2005-2007 var slegið 2016-2018, pegar 18.724 fleiri erlendir ríkisborgara fluttu til landsins en frá pví. Heimild: Hagstofa Íslands og útreikningar höfunda.

8 Störfum í ferðapjónustu og tengdum greinum á Íslandi fjölgaði úr 15.600 árið 2008 í 24.700 árið 2018. Árið 2013 voru útflutningstekjur af ferðapjónustu 131 milljarður króna en árið 2018 voru pær orðnar 337 milljarðar. Heimild: Hagstofa Íslands. 
pegar litið er til annarra pjóða sem gengu í gegnum mikla erfiðleika á sama tíma. ${ }^{9}$ Prátt fyrir pað býr íslenskt viðskiptalíf og samfélag við svipað skipulag og áður og fjármálakerfi sem starfar að talsverðu leyti eftir sömu reglum.

Рað má pó með sanni segja að umgjörðin hafi verið hert með ýmsum hætti, kröfur um hærra eigið fé banka og pá hefur Seðlabankinn ýmsar nýjar heimildir til inngripa. Prátt fyrir petta hefur pegar borið á umdeildum ráđstöfunum eigna úr bönkum, himinháum bónus- og launagreiðslum, háum arðgreiðslum, vandræðum fjárfestingarsjóða og öðru sem minnir á árin fyrir hrun. Pví má að sumra mati segja að sama kerfið sé við lýði, bara örlítið fleiri hringtorg og hraðahindranir á leiðinni (Stefán Ólafsson, 2016). Aðrir telja að gerðar hafi verið viðamiklar breytingar á regluverki fjármálafyrirtækja og pað sé nú gerólíkt pví sem pað var 2007 (Ásgeir Jónsson, Jónas Fr. Jónsson og Yngvi Örn Kristinsson, 2016).

\section{Rannsóknaraðferð}

Markmið greinarinnar er að skoða hvort stjórnunarhættir íslenskra stjórnenda hafi breyst eftir efnahagshrunið 2008. Til að ná pví markmiði voru spurningar sendar á íslenska stjórnendur sem allir eiga pað sameiginlegt að hafa verið í stöðu stjórnenda fyrir og eftir hrunið árið 2008 og pekkja pví vel til. Í rannsókninni var stuðst við eigindlega aðferð og leitast eftir að skilja efnið út frá sjónarhóli pátttakenda í rannsókninni, lýsa pví sem par kemur fram og túlka merkingu peirra upplýsinga sem fást með aðferðinni, en hún veitir möguleika á að fá vitneskju og pekkingu hlutaðeigandi aðila á viðfangsefninu (Bryman og Bell, 2007; Gephart, 2004). Rannsóknarspurningin sem lögð er til grundvallar í pessari grein er: Hafa stjórnunarhættir íslenskra stjórnenda breyst eftir efnahagshrunið 2008?

Til að hægt væri að ná fram mati stjórnenda á pví hvort stjórnunarhættir hefðu breyst eftir efnahagshrunið 2008 var nauðsynlegt að ná til stjórnenda sem höfðu gegnt pví hlutverki bæði fyrir og eftir efnahagshrunið og fá fram skilning peirra og túlkun á pví hvort breytingar hefðu átt sér stað. Pví var stuðst við hentugleikaúrtak við val á pátttakendum í rannsóknina (Dornyei, 2007) af lista Keldunnar um 300 stærstu fyrirtæki landsins 2017 og valdir 100 stjórnendur sem uppfylltu skilyrðin, að hafa verið stjórnendur fyrirtækja fyrir og eftir hrunið 2008. Stjórnendurnir fengu spurningar með tölvupósti par sem rannsókninni var lýst og leitað var eftir pátttöku peirra, í nóvember 2017. Alls bárust svör frá 52 stjórnendum, fjórir peirra vildu ekki svara, prír sögðust ekki hafa tíma til að svara og aðrir prír sögðust ekki hafa næga yfirsýn yfir rannsóknarefnið til að svara. Alls voru pað pví 42 stjórnendur af 100 er svöruðu spurningunum.

Í pessari grein er aðeins unnið með svör stjórnendanna við spurningunni hafa aðferðir stjórnenda breyst eftir efnahagshrunið á Íslandi árið 2008. Hins vegar, pegar farið var að greina svör viðmælenda kom í ljós að meira en helmingur peirra nefndi í svörum sínum eitthvað tengt árinu 2007. Pví var ákveðið að senda aftur á pá sem pannig svöruðu í apríl 2018 og par var spurt „Pegar sagt er að eitthvað sé í anda „2007“ hvað er pá átt við að pínu mati?".

Stjórnendum var heitið trúnaði og pví eru svör peirra einungis sett fram eftir kyni og starfsvettvangi í pessari grein en ekki nafni. Alls svaraði 31 karlmaður og 11 konur spurningunum. Stjórnendurnir starfa á sviði fjármála-, verslunar og pjónustu, flutninga-, fjarskipta-, fasteigna- og framleiðslustarfsemi, upplýsingatækni, heildsölu og flugtengdrar starfsemi.

Sú spurning sem hér er til grundvallar var opin spurning par sem stjórnendur máttu skrifa eins mikið og peir vildu. Við ítarlega greiningu svara var leitað eftir pemum er endurspegla viðfangsefnið helst. Gerður var listi yfir kóða sem voru pó nokkrir í upphafi en fækkaði pegar leitað var eftir tengslum kóða og pema (Gill, 2000). Í lokin stóðu svo prjú pemu eftir og verður gerð grein fyrir peim í niðurstöðum. Svörum viðmælenda er ekki ætl-

9 Alpjóða gjaldeyrissjóðurinn (e.d.) talar um „einstakan viðsnúning“ (e. spectacular turnaround) á Íslandi eftir hrun fjármálakerfisins. 
að að hafa alhæfingargildi (Sigurlína Davíðsdóttir, 2003), einungis að auka skilning lesenda á pví hvort peir stjórnendur sem svöruðu telja að stjórnunarhættir hafi breyst eftir hrun.

\section{Niðurstöður}

pegar litið er til pess hvað hefur breyst í aðferðum stjórnenda frá pví fyrir hrun birtust prjú meginpemu í svörum stjórnendanna sem mynda niðurstöður rannsóknarinnar. Pau eru áhættusækni, hugtakið 2007 og hroki og ábyrgðarleysi.

\section{1 Áhættusækni}

Undir pemanu áhættusækni greindust aðallega tveir kóðar sem eru varkárni og skuldsetning.

\subsubsection{Varkárni}

Varkárni var ofarlega í huga margra viðmælenda í samhengi við stjórnunarhætti og viðhorf stjórnenda í viðskiptalífinu, sem eitthvað sem hefur breyst á árunum eftir hrun. Viðmælendur segjast hafa tamið sér meiri varkárni við töku ákvarðana og að áherslur í fjármálageiranum séu varfærnari en fyrir hrunið. Karlmaður, stjórnandi í verslunargeiranum, telur að stjórnendur hafi tamið sér meiri varkárni í ákvörðunum sínum en fyrir hrun og meiri hógværð og auðmýkt. „,Dað er meiri virðing fyrir regluverki en var. Minna horft á skyndilausnir en meira til langtímauppbyggingar". Fleiri stjórnendur taka undir petta og karlkyns stjórnandi i fjármálafyrirtæki telur gildismat vera annað nú en fyrir hrunið og áherslur varfærnari en pær voru, „ég held að parna í nokkur ár í aðdraganda hrunsins hafi orðið til aðferðir sem eru nokkuð ólíkar poí sem nú tíðkast". Karlkyns stjórnandi í verslun sagði: „Við förum örlítið hægar en áður, ekki alveg jafnmikill hraði og meira um sameiginlega ákvarðanatöku en áður. Menn vilja tryggja sig betur en fyrir hrun, sérstaklega eftir alla dómana, pá passa menn sig betur og vilja ástunda heiðarleg vinnubrögð par sem allt er uppi á borðum. Pað finnst mér breyting“.

Pá telja stjórnendur að margt hafi breyst eftir efnahagshrunið. Peim er tíðrætt um óttann við mistök, að hann hafi verið alls ráđandi en sé nú, rúmum tíu árum síðar að nálgast ört pað sem áður var en með aðeins meiri varkárni en áður pekktist. Kona, stjórnandi í heildsölugeiranum segir: ,[Aðferðirnar] hafa að mínu mati einna helst breyst í pá veru að sjálfstraustið og áræðni til ákvarðanatöku er minni eftir hrun. Detta mikla sjálfstraust sem einkenndi íslenska stjórnendur fyrir hrun er ekki einkennandi fyrir stjórnendur í dag".

Kona sem er stjórnandi hjá fjarskiptafyrirtæki, er á svipuðu máli og segir:

Pað hægðist á ákvarðanatökunni eftir hrunið vegna færri tækifæra en nú pegar peim fjölgar í uppsveiflunni eru ákvarðanirnar aftur teknar hraðar, en nálægðin við hrunið hefur pau áhrif að menn horfa á fleiri fleti áður en pær eru endanlega teknar.

Pá var stór hluti stjórnenda sammála um að dregið hefði úr áhættusækni og að undirbúningur nú væri meiri fyrir ýmis mál en fyrir hrun og að aðilar hefðu meiri framtíðarsýn en áður. Pá væru stjórnendur meðvitaðri um framtíðarhorfur og betur í stakk búnir til að takast á við breytingar með skömmum fyrirvara. Karlmaður í upplýsingatækni segist hins vegar ekki merkja neina sérstaka breytingu á stjórnunarháttum en pað sé kannski helst að menn séu „ögn varari um sig en áður og varkárari”. Aðrir segjast taka eftir meiri varkárni en líkt og karlkyns stjórnandi í pjónustufyrirtæki segir pá birtist pað fyrst og fremst í ,áætlanagerð um alla skapaða hluti” eins og hann orðaði pað. Karlkyns stjórnandi i flugtengdri starfsemi, kemst pannig að orði:

Vá pað hefur svo margt breyst. Erum komin inn á petta að funda út í eitt sem var ekki áður, allir verða að vera upplýstir og fáir pora að taka ákvarð- 
anir án pess að vera í björgunarvestunum. Við viljum „,fljúga“ í vestunum líka í viðskiptalífinu og passa að enginn geti hankað okkur á neinu.

Aðrir taka í sama streng og telja að formfesta hafi aukist innan fyrirtækja eftir hrunið. Undirbúningur sé betri, skipulag hafi aukist og meiri tími sé gefinn til töku ákvarðana og í áhættumat. Kvenkyns stjórnandi í verslun segir „,petta var svona fyrstu árin eftir hrunið, en er að breytast og fxrast aftur i líkara far og var fyrir hrun. Menn eru að fá sjálfstraustið aftur og pá dregur úr varkárni og ofurskipulagi“. Pá telur stjórnandi í ferðapjónustu íslenska stjórnendur hafa tamið sér meiri aga, formfestu og ferlavinnu í meira mæli eftir hrun og telur pað jákvætt. Kvenkyns stjórnandi í upplýsingatækni segir „,við erum að fara í sama farið aftur".

\subsubsection{Skuldsetning}

Seinni kóðinn sem myndaðist undir áhættusækni er skuldsetning en pað var eitt af pví sem einkenndi bæði erlendar fjárfestingar Íslendinga, sem og samfélagið í heild sinni á árunum fyrir hrunið. Karlkyns stjórnandi hjá framleiðslufyrirtæki segist verða var við "minni áhættusækni, meira kostnaðaraðhald og ákveðið ópol fyrir öfgum". Hann sagði viðhorf til skuldsetningar annað og "ákveðið afturhvarf til íhaldssamra gilda“. Hann segir minna horft á skyndilausnir og að meira sé um langtímauppbyggingu. Pá bætir hann við ,„pað er meiri skilningur fyrir poí að hafa tekjur og útgjöld i sömu mynt". Pá telur kvenkyns stjórnandi í framleiðslugeiranum lítið hafa breyst annað en að, ,fólk hafi kannski lært að taka ekki allt á láni og skuldsetja sig poí minna".

Karlkyns stjórnandi hjá framleiðslufyrirtæki telur ástandið hafa breyst um tíma, rétt eftir hrun, en allt sé komið af stað aftur. Hann sagði „Atvinnulífið er komið á fullan hraða og snýst um að drífa hlutina af og klára all strax... petta er kannski ekki eins skuldsett og ádur, og pó".

Karlmaður sem er í stjórnandi í flutningafyrirtæki, tekur í svipaðan streng og segir:

Stjórnendur lærðu áreiðanlega mjög mikið í gegnum hruntímann og árin par á eftir og pað verður stjórnendum dýrmætt veganesti og mun marka stíl peirra að einhverju leyti. Pað hefur lítið breyst hjá okkur og ég held pví miður að við höfum ekkert lært af hruninu. Við erum hins vegar ekki eins mikið í 'leverage buying' og 'buy-out' eins og áður. Við erum með meira eigið fé núna og nýtum pað til kaupa og fjárfestinga.

Pá nefnir karlkyns stjórnandi í framleiðslufyrirtæki að Íslendingar hafi að vissu leyti lært sína lexíu á hruninu.

Blessaða hrunið já, ég held að við höfum lært okkar lexíu. Að minnsta kosti að vissu leyti. Í dag er enginn að tala um að fjármagna fyrirtækjakaup erlendis eins og gert var áður og menn spá meira í stærðina en peir gerðu á væntum kostum. Við erum meira í okkar deild ef svo má segja. Við vorum í priðju deild og vorum að kaupa fyrirtæki í úrvalsdeild.

Kona sem er stjórnandi í framleiðslufyrirtæki er ósammála og hún segir:

Jú við höfum kannski verið varkárari [eftir hrunið] en mér finnst pað vera að breytast aftur núna 10 árum síðar. Kannski er petta bara hringferill sem gengur í 10 ár. Pað er lægð og svo smám saman fara hlutirnir upp og stjórnendur í essinu sínu til 2006/2007 og svo kom hrunið og hægðist á öllu og nú er aftur blússandi stuð hjá stjórnendum. Sum fjármálafyrirtæki byrjuð aftur í útrás til sömu landa.

Pá nefnir annar kvenkyns stjórnandi í pjónustugeiranum „Ég er í samskiptum við fyrirtæki sem er t.d að fara út núna á erlenda markaði, að opna útibú og pað er meira að segja með sömu leikmönnum og fyrir hrunið“". 
Karlmaður sem er stjórnandi í fjármálafyrirtæki og hefur verið í peirri atvinnugrein lengi segir að рað sem sé öðruvísi nú en fyrir hrun sé að stjórnendur séu með meiri langtímahugsun, væru að horfa aðeins lengra fram í tímann:

Раð sem er aðeins öðruvísi núna er að við hugsum aðeins meira en nokkra mánuði fram í tímann. Nú erum við með meira eftirlit með okkur og við plönum alveg 1-2 ár fram í tímann. Áður póttu sex mánuðir vera langtímaplan. Við erum svo skrýtnir Íslendingar. Menn eru líka að fara af stað í skuldabréfaútgáfu. Pottpétt stutt í að fyrirtækin fari að tilkynna um skuldabréfaútgáfu.

Kona sem er stjórnandi í framleiðslufyrirtæki er á öðru máli, hún segir stjórnendur ekki ennpá hafa lært að gera og vinna eftir langtíma áætlunum sem er neikvætt. Eins segir hún "mér finnst skorta að fólk læri að taka ábyrgð". Karlmaður sem er stjórnandi í fjármálafyrirtæki segir að til að byrja með hafi stjórnendastíll breyst en jafnframt: „pegar losna fór um eignarhaldið og nýir eigendur komu að fyrirtækjunum pá snérist stjórnunin aftur upp í hreina eiginhagsmuni og að auka verðmæti peirra eignarhluta á sem skemmstum tíma“.

\section{2 hugtakið - 2007}

Ártalið 2007 er orðið pekkt sem ,"hugtak“ með ákveðinni merkingu sem flestir yfir prítugu á Íslandi virðast leggja svipaðan skilning í. Pegar stjórnendur voru beðnir að skilgreina hvað 2007 stæði fyrir í peirra huga komu ýmis svör en öll áttu pað sameiginlegt að tákna bruðl, að еyða um efni fram og lítið kostnaðaraðhald. Karlmaður sem stýrir fyrirtæki í upplýsingatækni segir „2007 pýđir ástand, athöfn eða viðhorf sem einkennist af flottheitum umfram raunverulegt ástand. Að lifa um efni fram eða leyfa sér hluti án pess að velta fyrir sér hoað peir kosta". Karlkyns stjórnandi í upplýsingatækni svarar pví til pegar hann var spurður fyrir hvað 2007 stæði sagði hann ,, bruðl, hroki og yfirgangur, græðgi, skammsýni og raunveruleikafirring voru einkennandi fyrir pennan tíma".

Kvenkyns stjórnandi í upplýsingatækni segir „ef ég ætti að skilgreina 2007 pá myndi ég nota orð eins og kjánalegt, barnalegt, digurbarkalegt, byggir á forsendum sem eru ekki til staðar". Раð sem flestir stjórnendur eru sammála um er að nóg virðist hafa verið af fjármagni í umferð, að aldrei hafi verið spurt út í kostnað og eytt um efni fram. Kona, stjórnandi í fjármálafyrirtæki orðar pað pannig „Bullandi gangur alls staðar og eytt um efni fram. Aldrei spurt út í kostnað, einkaflugvélar og sjampó"

Aðrir taka dýpra í árinni og karlkyns stjórnandi í framleiðslufyrirtæki segir:

Andi 2007 pýðir í mínum huga óraunsæi og reynsluleysi varðandi efnahagslegar væntingar og óhóf í tilkostnaði og veisluhöldum auk viðamikillar og skipulagðrar fjármagnstengdrar glæpastarfsemi. Með pví á ég t.d. við óheiðarleika sem felst t.d. í fölsuðum ársreikningum pegar bankar lána út á eigið fé, en draga pað ekki frá í ársreikningi. Greiningardeild stærsta bankans talar upp gengi krónunnar og lífeyrissjóðum talin trú um að taka stöðu, á meðan eigendur bankans og vinnuveitendur greiningardeildar taka stöðu í hina áttina. Peningamarkaðs- og verðbréfasjóðir eru látnir taka fáránlega áhættu á suma aðila, sem sumir eru tengdir banka eða hluthöfum. Dæmin eru gríðarlega mörg og stór og petta er ekki hætt sbr. Arion, Frjálsi lífeyrissjóðurinn og United Silicon pegar lífeyrissjóður í umsjón bankans kemur með eigið fé inn löngu eftir að lán bankans kemst í uppnám. Við eigum svolítið í land, pví miður.

Pá benda sumir á að lítið hafi breyst að pví leyti að sömu leikendur séu komnir aftur að borðinu og nú tvíefldir. Karlmaður sem stýrir heildsölufyrirtæki segir: 
Að mínu mati tel ég að fjármálafyrirtæki (bankar, fjárfestingasjóðir í umsjón banka ofl.) séu orðnir mjög fyrirferðamiklir gerendur í íslensku atvinnulífi par sem oft er verið að kasta fjármunum á glæ með vonlausum fjárfestingum (United Silicon, hótelbyggingar o.fl). Einnig tel ég yfirbragð pessara fyrirtækja minna um margt á pað sem maður sá fyrir 2007 með íburði og glæsileika (óhófi) sem almenn fyrirtæki gera ekki. Рað sem undirstrikar petta núna eru fréttir af sölu Skeljungs frá 2008 og hvernig gerendur í pví leikriti eru orðin umsvifamikil í skráðum fyrirtækjum s.s. TM, VÍS og svo Kviku.

En ef vikið er aftur að rannsóknarspurningunni, hvort eitthvað hafi breyst í íslensku efnahagslífi pá eru svörin á pennan veg. Karlmaður í fjármálafyrirtæki nefnir að til að byrja með hafi stjórnunarhættir breyst eftir hrunið.

...pá báru [stjórnunarhættirnir] pess merki að hjá mörgum leiðandi fyrirtækjum og fjármálastofnunum voru menn ráðnir vegna pess að peir voru „klín“ en ekki vegna pess að peir voru peir bestu á markaðnum. Pessir stjórnendur voru uppteknir við að uppfylla hreinleika endurreisnarinnar og ákvarðanir teknar sem uppfylltu pær parfir. Petta voru linir stjórnendur.

Hann telur að pegar leið á og uppsveiflan fór að segja aftur til sín hafi allt breyst í fyrra form, eins og pað var fyrir hrunið. Stjórnandi í heildverslun tekur undir og segir , að undanfarin misseri hafi sést merki um 2007 í ákveðnum geirum og pá sérstaklega ífjármálageiranum". Pá segir kvenkyns stjórnandi í framleiðslufyrirtæki aðspurð hvort eitthvað hafi breyst: ,Já jesús, 2007 all over again. Ég hélt í alvöru að við hefðum lært meira af hruninu, en pað virðist ekki vera... En kampavinið er farið að flæða aftur og ég fæe ekki frið fyrir allskonar gylliboðum".

Karlkyns stjórnandi í framleiðslufyrirtæki er sammála og segir „boðsferðir, gjafir og glamúr er komið á fullt aftur". Karlkyns stjórnandi í pjónustugeiranum talar um að̃ ",allt sé fljótandi i víni aftur og að djammið sé komið á fullt" hann nefnir einnig að veiði- og aðrar boðsferðir séu komnar aftur á dagskrá fyrirtækja. Karlmaður, stjórnandi í fjármálafyrirtæki tekur undir og segir nákvæmlega ekkert hafa breyst. Hann talar um að menn hafi farið í felur í nokkur ár en nú „eru menn að fara í sama andskotans gírinn og fyrir hrun”, hann heldur áfram:

[menn eru aftur] farnir að söðla undir sig stöndug félög sem hefur verið bjargað og löguð eftir vitleysuna sem viðgekkst og nú kemur petta af fullum punga aftur. Ég meina pað parf ekki annað en að horfa á markaðinn, við erum að sjá pað nákvæmlega sama gerast aftur og fyrir hrun. аð koma einhverjir misgáfulegir fjárfestar og reyna að söðla undir sig banka og tryggingafélög.

Margir stjórnendanna nefndu að lítið ef nokkuð hefði breyst frá hruni og tveir nefndu að ný uppsveifla væri í gangi og að hegðun stjórnenda væri í takti við pað. „Erum að fara í sama farið aftur" segir kona sem er stjórnandi í upplýsingatækni. Karlmaður, stjórnandi í pjónustufyrirtæki segir aðspurður hvort eitthvað hafi breyst ,já og nei, mikið um rugl í dag sem ekki var fyrstu árin eftir hrun. Djamm, veiðiferðir og boðin, allt fljótandi í víni aftur og ferðapjónustan er að ýta undir petta í gegnum svo margt annað“.

Kvenkyns stjórnandi í fjármálafyrirtæki sagði að mikið hafi breyst strax eftir hrun og nefndi aðhaldssemi, uppsagnir og tvöpúsund og sjö hegðun eins og að piggja boð í veiði hafi verið tabú. En að ástandið væri annað í dag, hún komst svo að orði:

Adam var ekki lengi í „,helvíti”. Nú er allt í full swing og erum við komin aftur par sem við vorum á árunum fyrir hrun. Maður sér pað meðal annars 
á utanlandsferðum fyrirtækja með sína starfsmenn, launapróun og svona mætti lengi telja. Bankastjórar og stjórnendur stærstu fyrirtækja eru aftur komnir með ofurlaun en millistjórnendur sitja eftir.

Pá benda margir stjórnendur á að petta sé allt komið aftur, í mismiklum mæli pó. Bankarnir buðu viðskiptavinum sínum á fótboltaleiki, meðal annars á heimsmeistaramótið 2018. Pá hefur orðið mikið launaskrið, par sem forstjórar og bankastjórar leiða vagninn.

Karlmaður sem stýrir heildsölufyrirtæki segir allt vera komið á svipaðan stað og fyrir hrun. Hann nefnir ",meiri eyðsla, meiri áhættutaka, meiri fjárfestingar“. Eins segir hann: „[Við] erum í sápukúlunni og hún er bara nýútblásin, á eftir að stækka og vonandi springur hún ekki með sama hvelli og áður". Stjórnendur nefndu einnig að almennt hugsi peir meira um ásýnd en áður var og séu meðvitaðri um ákveðnar athafnir og lífsstíl sem kenndur er við 2007 og vilji helst ekki láta kenna sig við hann lengur.

Kona sem stýrir verslunarfyrirtæki segir:

Fyrir hrun pegar uppgangurinn var sem mestur pá gátu Íslendingar allt og höfðu mikið sjálfstraust, gátu allt og ekkert var peim óviðkomandi pegar kom að fjárfestingum. Ferðuðust út um allan heim og alltaf á fundum með aðilum úti. Раð pótti flott. Íslenskir stjórnendur fóru svo í algjöran baklás eftir hrun. Рað mátti ekki neitt, peir gátu ekki neitt og sjálfstraustið fór bara í mola, fóru með veggjum á erlendum sýningum og fundum. Tveir hjá mér neituðu t.d að fara á ráđstefnur erlendis fyrst eftir hrun, peir skömmuðust sín svo mikið, pað var búið að eyðileggja ásýndina.

Nokkrir aðrir stjórnendur eru sammála um að stjórnendur í dag forðist ákveðnar athafnir sem einkenndu árin fyrir hrun eins og of mikla risnu, of stórar gjafir og mikið prjál pótt slíkt sé enn til staðar. Karl sem er stjórnandi í framleiðslufyrirtæki segir ,,við höfum lítið lært en við erum meira undercover en ádur. Menn eru ekki að flika hlutunum eins mikið í dag og fyrir hrun. Fara örlítið fínna í petta ef svo má segja“.

Annar nefnir ,"við erum ekki eins mikið að láta sjá okkur í Séð og Heyrt eins og ádur, við fordumst pað eins og kostur er". Enn einn tekur undir og segir „ég vil ekki vera á forsíðunni sem stjórnandinn sem býđur í utanlandsferðir, veiði eða slíkt, ég bara vil pað ekki, jafnvel pótt við myndum oft bestu samböndin í veiðiferðunum, pá vil ég pað ekki“.

\subsection{Hroki og ábyrgðarleysi}

Eins og fram hefur komið pá fór mikið fyrir stjórnendum fyrirtækja sem voru áberandi í alpjóðaviðskiptum á árunum fyrir hrunið. Petta póttu ungir stjórnendur sem lögðu mikið upp úr persónulegum samböndum og treystu á eigið innsæi, frekar en töluleg gögn. Pá hafa rannsóknir sýnt fram á að íslenskir stjórnendur treysta minna á formlegar reglur, peir pykja bjartsýnir og pað jaðrar við kæruleysi. Petta gæti birst sem hroki gagnvart öðrum. Margir stjórnendur nefndu petta í svörum sínum en með mismunandi hætti.

Kvenkyns stjórnandi í framleiðslugeiranum telur ekkert hafa breyst í stjórnunarháttum og segist ekki sátt: „Burt með pann hroka sem er í gangi i íslensku atvinnulífi og stjórnmálum“. Aðrir stjórnendur nefna einnig pennan hroka og mikilmennsku brjálæðið sem einkenndi viðhorf stjórnenda á árunum fyrir hrun. „Við vorum langflottastir, við gátum allt, kunnum allt, vorum betri en hinir, keyptum allt sem við komumst i, opnuðum skrifstofur í öllum krummaskuðum og ætluðum okkur heimsyfirrád“" sagði karlmaður sem stýrir framleiðslufyrirtæki.

Hann heldur áfram og segir að pað hafi dregið aðeins úr pessu viðhorfi við hrunið, en nefnir jafnframt að kjarkurinn sé kominn aftur og hrokinn eftir pví. Kvenkyns stjórnandi tekur undir petta og segir ",[F]yrir hrun pegar uppgangurinn var sem mestur pá gátu Íslendingar allt. Ég á petta, ég má petta og mikið sjálfstraust... [peir] gátu allt og ekkert var peim óviðkomandi pegar kom að fjárfestingum“. Hún segir sama viðhorf ríkjandi í dag og nefnir 
tíðar utanlandsferðir og stanslausa fundi erlendis sem dæmi um slíkt. Karlmaður, stjórnandi í framleiðslufyrirtæki tekur í sama streng og segir: "mér finnst hrokinn líka alls ráðandi“ og hann hneykslar sig einnig á pví ábyrgðarleysi sem sé ríkjandi. Annar stjórnandi í pjónustugeiranum telur ástandið hafa breyst um tíma eftir hrun og að „stjórnendur hafi farið í ákveđinn baklás“, en annað sé uppi á teningnum í dag par sem stjórnendur hafi öðlast fullt sjálfstraust að nýju og séu „egocentrískari núna en fyrir hrun“. Hann segir 2007 vera komið aftur „1́ öðru veldi“ og segir „ég ég ég“ einkennandi fyrir tíðarandann í dag og „petta reddast" pað hefur ekkert breyst.

Kvenkyns stjórnandi í pjónustugeiranum telur stjórnunarhætti ekki hafa breyst frá hruni. Hún segir ákveðinn stíl og mikið sjálfstraust og hroka vera einkennandi:

Ef við skoðum petta út frá stjórnunarháttum pá hefur nákvæmlega ekkert breyst, við erum með sama stílinn og fyrir hrun, ákveðinn, agressífan stíl og mikið sjálfstraust. Ég er í samskiptum við fyrirtæki sem er að fara aftur á erlenda markaði, að opna útibú og pað er meira að segja með sömu leikmönnum og fyrir hrunið. Нvað er pað? voru ekki allir hreinsaðir út hérna eftir hrunið. Раð mátti enginn neitt og öll reynsla hvarf úr fjármálafyrirtækjunum. Finnst fólk enn vera að súpa seyðið af pví að hafa einu sinni unnið á einhverjum stað, en greinilega ekki allir. Strákarnir eru mættir aftur en bara svo pað sé sagt pá finnst mér alltof hart hafa verið gengið fram eftir hrunið að hreinsa út knowledgeið úr fyrirtækjunum og mörgum hreinlega slátrað. Menn voru á lista. Fólk sem átti pað jafnvel alls ekki skilið. En stjórnendur eru komnir með sjálfstraustið aftur farnir að láta meira bera á sér. Ekki pessi Se og hør stíll sem var.

Fleiri taka undir, t.d kvenkyns stjórnandi í hugbúnaðarfyrirtæki sem nefnir að við höfum lítið lært af efnahagshruninu. Hún segir „,Pað er ótrúlegt hversu lítið við höfum í raun og veru lært, pað er bara komin ný uppsveifla og allt á blússandi swingi núna, en ég hef áhyggjur af pví að við höfum lítið lært af hruninu sem vard̆“. Íslendingar trúa kannski ekki á banka ${ }^{10}$ árið 2019 en af svörum stjórnenda má ráða að sjálfstraustið virðist vera að vakna aftur.

\section{Umræða}

Fjölmargir pættir hafa áhrif á stjórnunarhætti og samkvæmt Armstrong (2006) mótast peir af persónuleika einstaklingsins og menntun hans, pví umhverfi sem hann starfar í og menningu fyrirtækisins sem hann starfar hjá. Rannsóknir á íslenskum stjórnendum hafa leitt í ljós að pað sem einkenni íslenska stjórnendur sé frumkvöðlahneigð, stéttleysi, óformleg samskiptahefð, áhættusækni og hraði.

Við greiningu svara stjórnendanna mynduðust ákveðin pemu sem greint hefur verið frá. Pau eru áhættusækni, 2007 og hroki og ábyrgðarleysi og voru pau gegnumgangandi hjá öllum viðmælendum, pó mismunandi framsett.

Sé litið til áhættusækni pá hafði tæpur helmingur viðmælenda orð á varkárni á einn eða annan hátt. Margir stjórnendur voru á pví að fólk sé hræddara við að taka ákvarðanir og vilji helst vera með belti og axlabönd pegar kemur að ákvarðanatöku og að nú velji stjórnendur öryggið umfram áhættuna. Pá sögðu stjórnendur að meira hefði verið um langtímastefnumótun á árunum eftir hrun heldur en áður. Rímar pað við niðurstöður Inga Rúnars Eðvarðssonar og Guðmundar Kristjáns Óskarssonar (2009). Pá vildu aðrir stjórnendur meina að pað hefði verið ákveðin varkárni eftir efnahagshrunið, sérstaklega á árunum 2009-2013 en hún væri ekki til staðar í dag, áhættusækni hefði aukist að nýju og hlutirnir væru að fara í sama horf og áður. Pá benti Már Guðmundsson páverandi banka-

10 Gallup (2018) mældi traust almennings til ýmissra stofnana samfélagsins í febrúar 2018. Bankakerfið reyndist með minnsta traust peirra sem spurt var um eða 20\%. Рað var pó aukning frá árinu áður og hefur traustið aukist nokkuð frá pví pað var minnst rétt eftir hrun. 
stjóri Seðlabanka Íslands á pað árið 2018 að vísbendingar væru um að áhættusækni væri að vaxa í íslensku bankakerfi og eftirlitsaðilar purfi að sjá til pess að hún gangi ekki of langt (Seðlabanki Íslands, 2018, bls. 3).

Meira en helmingur viðmælenda notaði árið 2007 sem hugtak og lýsingarorð, yfir ástand par sem græðgi og taumleysi hefði ríkt. Engin kostnaðarvitund hefði verið til staðar og menn eyddu um efni fram. Pá vildi um fjórðungur viðmælenda meina að hroki og ábyrgðarleysi hefði ríkt og ríkti enn í íslensku viðskiptalífi. Hroki og ábyrgðarleysi birtist í pví að stjórnendur taka ákvarðanir og hugsa síðar um afleiðingarnar, ,,Við vorum langflottastir, við gátum allt, kunnum allt, vorum betri en hinir, keyptum allt sem við komumst i, opnuðum skrifstofur í öllum krummaskuðum og ætluðum okkur heimsyfirrád“. Ho, Huang, Lin og Yen (2016) sýndu fram á að bankastjórar með of mikið sjálfstraust drógu úr kröfum til lántakenda og juku vogun og Haukur Freyr Gylfason, Friðrik H. Jónsson og Haukur C. Benediktsson bentu á bæði 2006 og 2007 að sjálfstraust sérfræðinga á íslenskum fjármálamarkaði og trú peirra á eigin getu hefði almennt verið of mikil og slíkt hefur áhrif á stjórnunarhætti samkvæmt Goleman og Early, (2005). Mörg íslensk fyrirtæki sóttu mjög hratt og stíft á erlenda markaði á árunum fyrir hrun, sem jók áhættu, kannski vegna prýstings frá hluthöfum. Pó stjórnendur hafi verið á pví að dregið hafi úr pessu eftir hrun má pó greina að petta sé að mörgu leyti að koma aftur, að stjórnendur séu að verða kjarkmeiri að nýju, að sjálfsálitið sé að koma til baka, peir taki ákvarðanir hraðar og að margt minni að nýju á árin fyrir hrunið.

Hraða ákvarðanatöku mætti rekja til fámennis og einangrunar, en einnig til óttaleysis hjá íslensku pjóðinni sem er vön að takast á við sviptingar í náttúrunni. „Reddaragenið“ er hugtak sem rekja má til ummæla Davíðs Oddssonar, fyrrverandi forsætisráðherra, pegar hann lýsti Íslendingum og hvernig pjóðinni tókst að skipuleggja mikilvægan fund stórveldanna í Höfða árið 1986 með afar stuttum fyrirvara. Î pessu samhengi kemur jákvætt viðhorf Íslendinga í ljós par sem oft og tíðum er stokkið í djúpu laugina og ætlast til pess að hlutirnir bjargist einhvern veginn. Petta má greina í svörum stjórnendanna, bæði sem hroka og ábyrgðarleysi, en einnig sem hluta af skýringunni á pví hvað 2007 stendur fyrir. Að margt af pví sem peir telja að hafa einkennt árið 2007 sé komið aftur „1́ öðru veldi“ og „ég ég ég“ sé einkennandi fyrir tíðarandann í dag, ,„petta reddast" pað hefur ekkert breyst. Petta er í samræmi við rannsóknir Hrafnhildar M. Eyjólfsdóttur og Smith (1996) sem og rannsóknir Kristínar Loftsdóttur og Helgu Björnsdóttur frá árinu 2015, en par kemur fram að fólk sem aðhyllist áhættu, pað taki frekar óraunhæfar og fjárhagslega skaðandi ákvarðanir án pess að reikna dæmið til enda. Рað lætur leiðast af svokölluðu lottóhugarfari. Pá stjórnast áhættusækið fólk ekki síður af hinu sér íslenska viðhorfi um að „petta reddast“.

Viðmælendur voru sammála um pað að ýmislegt hefði breyst eftir hrunið. Stjórnendur hefðu farið í meiri stefnumótun og væru meira að hugsa til lengri tíma en áður. Viðhorf til skuldsetningar væri annað en áður og ákveðið afturhvarf væri til íhaldsamra gilda, kannski borin meiri virðing fyrir regluverki en var fyrir hrunið. Pá er umhverfið að breytast og pættir eins og jafnlaunavottun, umhverfissjónarmið og meðferð persónuupplýsinga gerir kröfur á stjórnendur að pessum málum sé sinnt. Fyrir hrunið var lítil eftirfylgni með pessum páttum en nú er búið að festa petta í lög sem pýðir að pessir pættir hafa meira vægi.

Stjórnendum var tíðrætt um að „glamourinn“ væri kominn aftur í íslensku viðskiptalífi, boðsferðir og kampavín sem póttu einkennandi árið 2007. Pá nefndu stjórnendur að mikið hafi breyst strax eftir hrun og aðhaldssemi, uppsagnir og 2007 hegðun eins og að piggja boð í veiði hafi verið tabú. En að ástandið væri annað í dag, ",Adam var ekki lengi í helvíti" og allt væri komið á fulla ferð aftur, að ástandinu svipaði að sumu leyti til pess sem hefði verið fyrir hrun. Petta töldu stjórnendur að mætti greina á boðum í utanlandsferðir og á launapróun, að bankastjórar og stjórnendur stærstu fyrirtækja væru aftur komnir með ofurlaun. Petta er pví pvert á pað sem Jóhanna Sigurðardóttir, páverandi forsætisráðherra Íslands sagði á 138. löggjafarpingi (6. október 2009) um að tíma ofurlauna og kaupauka fyrir 
stjórnlausa áhættusækni væri lokið. Hún sagði jafnframt að ákvarðanir stjórnenda, stjórnarfólks og hluthafa á árunum fyrir hrunið, ,,ekki síst óhófleg áhættusækni, voru grundvöllur ofpenslu og síðar hruns bankanna". Раð er ljóst að pað hægði á ferlinu og margir stjórnendur tóku á sig miklar launalækkanir en pað virðist gjörbreytt í dag.

Pá nefndu stjórnendur að fjárfestar væru farnir að söðla undir sig stöndug félög sem bjargað var eftir hrunið og svipað ferli væri í gangi og fyrir hrun „,Раð koma einhverjir misgáfulegir fjárfestar og reyna að söðla undir sig banka og tryggingafélög“. Rannsóknir sem byggja á efnahagsreikningum fyrirtækja sýna að skuldsetning var árið 2014 orðin svipuð og á árunum fyrir hrun (Anna Rut Práinsdóttir og Gylfi Magnússon, 2016) og samræmist pví sem fram kom í svörum stjórnenda.

Rannsóknir á einkennum og aðferðum íslenskra stjórnenda á árunum fyrir hrun bentu til pess að peir væru áhættusæknir og fljótir að taka ákvarðanir. Sjálfstraustið var mikið og birtist jafnvel í hvatvísi, pá virtist skortur á langtímastefnumótun. Pví var skoðað hér hvort pessi einkenni væru enn til staðar eða hvort aðferðir stjórnenda hefðu breyst. Í ljós kom að stjórnendur í íslensku atvinnulífi eru sammála um að margt hafi breyst í stjórnunarháttum frá pví fyrir hrun, óttinn við mistök hafi verið alls ráðandi í atvinnulífinu eftir hrunið en tíu árum síðar séu hlutirnir að nálgast ört pað sem áður var, pó hugsanlega sé aðeins meiri varkárni í ákvarðanatöku, meira regluverk og formfesta og meiri áætlanagerð en var.

Rannsóknarspurningin sem lögð var til grundvallar var hvort stjórnunarhættir íslenskra stjórnenda hefðu breyst eftir hrunið 2008. Margir stjórnendur svöruðu pví til að nú rúmum 10 árum eftir hrun, sé allt að fara í svipað horf og pað var, allt fljótandi í víni og boðsferðum fyrirtækja nema nú séu hlutirnir minna áberandi á yfirborðinu, meira bak við tjöldin. Pá hefur hroka og ábyrgðarleysi víða verið að finna í samfélaginu að mati peirra stjórnenda sem tóku pátt í rannsókninni, áhættusækni og hroki er meiri en var fyrst eftir hrun, ég á petta, ég má petta er eitthvað sem stjórnendur telja að sjáist nú meira bæði í viðskiptalífi og í stjórnmálum. Petta fellur vel að kenningum Robert Shiller $(2017,2019)$ um pað hvernig breytt orðræða hefur áhrif á hegðun. Umræðan snýst ekki um hrun, tap og sökudólga líkt og rétt eftir hrun. Hún er orðin jákvæðari og stjórnendurnir upplitsdjarfari. Pá fellur pað einnig að skrifum Guðrúnar Finnborgar Pórðardóttur og Hrafnhildar Mooney (2016) um að menning fyrirtækja fyrir hrunið hafi einkennst af of mikilli áhættusækni, takmarkaðri yfirsýn stjórnar og ofuráherslu á hagnað sem dreifðist á fáa aðila. Einnig að hjarðhegðun hafi viðgengist í stjórnum margra fyrirtækja.

Hér ber að geta að engan veginn er hægt að alhæfa neitt um aðferðir íslenskra stjórnenda fyrir eða eftir hrun, en svör stjórnendanna veita ákveðna innsýn og gefa vísbendingar um að margt hafi breyst en pó sé ýmislegt á svipuðum nótum og fyrir hrunið, er bara ekki eins sýnilegt og áður.

Nýnæmi rannsóknarinnar felur í sér að hér er veitt innsýn í hugarheim stjórnenda sem voru í stjórnunarstöðum fyrir hrunið og eru í stjórnunarstöðum í dag og hvað peir telja að hafi breyst á pessum tíma. Takmarkanir rannsóknarinnar felast í pví að hér er einungis verið að biðja um viðhorf stjórnenda, að peir líti til baka og rifji upp og einungis er um viðhorf 42 stjórnenda að ræða. Best hefði verið ef mælingar hefðu verið gerðar fyrir og eftir hrun meðal sömu einstaklinga. Pá væri áhugavert í frekari rannsóknum að taka djúpviðtöl við stjórnendur til pess að fá enn dýpri innsýn í hugarheim peirra um efnið.

Hagnýtt gildi pess að kortleggja pessa próun er ótvírætt. Pað gæti m.a. dregið úr líkum á að stjórnendur endurtaki í einhverri mynd pau mistök sem gerð voru í aðdraganda hruns. Spírallinn sem áður var minnst á virðist ekki vera dauður úr öllum æðum. Nýjar valdablokkir virðast vera að myndast með kunnuglegum aðalpersónum. Pá er ferðapjónustan á Íslandi í kröggum, hagræðing hefur átt sér stað og mun færri ferðamenn komu til landsins á árinu 2019, eftir ævintýralegan uppgang undanfarin ár, pá hafa stjórnvöld virkjað viðbragðsáætlun vegna pessa. Fréttir af fjárfestingarsjóðum í vandræðum eftir að hafa flogið hátt um skeið vekja líka misljúfar minningar og aukinn prýstingur er á veikara reglu- 
verk. Allt eru petta kunnugleg hugtök frá pjóðmálaumræðunni fyrir áratug. Pótt staðan sé engan veginn sambærileg og árið 2008 pá virðist ljóst að rússíbanareiðum íslensks efnahagslífs er ekki lokið.

\section{Heimildir}

Alpjóða gjaldeyrissjóðurinn. (e.d.). Iceland: Spectacular Turnaround from Financial Meltdown. https://www.imf. org/en/Countries/ISL/iceland-lending-case-study. Sótt 7.10.2019.

Anna Rut Práinsdóttir og Gylfi Magnússon. (2016). Fjármagnsskipan og fjárhagsleg staða fyrirtækja á Íslandi árin 2005 til 2014. Áhrif efnahagshrunsins og annarra pátta á skuldsetningu. Tímarit um viðskipti og efnahagsmál, 13 (2), 39-69.

Armstrong, M. (2006). A Handbook of Human Resource Management Practice. 10th Edition. London: Kogan Page Publishing.

Ásgeir Jónsson, Jónas Fr. Jónsson og Yngvi Örn Kristinsson. (2016). Hvað hefur breyst? Breytingar á regluverki fjármálamarkaða á Íslandi, i Evrópu og Bandaríkjunum i kjölfar fjármálakreppunnar. Reykjavík: Samtök fjármálafyrirtækja. Sótt af https://sff.is/sites/default/files/sff_umbotaskyrsla_2016_-_netutgafa_0.pdf.

Ásgeir Jónsson. (2015). Mikil gróska í nýsköpun í sjávarútvegi. RÚV. Sótt af https://www.ruv.is/frett/mikilgroska-i-nyskopun-i-sjavarutvegi

Ásta Dís Óladóttir. (2019). Nýsköpun og fæðuöryggi. Nýjar áskoranir í sjávarútvegi. Rannsóknir í félagsvísindum XX. Ágrip erinda flutt á ráðstefnu 1. nóvember 2019 Reykjavík: Félagsvísindastofnun Háskóla Íslands. ISBN 975-9935-424-26-6

Ásta Dís Óladóttir. (2009). Internationlization from a small domestic base: An empirical analysis of foreign direct investments of Icelandic firms. Management International Review, 49 (1), 61-80. DOI: 10.1007/s11575008-0125-6

Ásta Dís Óladóttir. (2006). Tvöfalt fleiri ætla að sækja út! Frjáls verslun, 68 (10), 18-29.

Bebchuk, L. og Fried, J. (2004). Pay without Performance : The Unfulfilled Promise of Executive Compensation. Cambridge: Harvard University Press.

Bryman, A. og Bell, E. (2007). Business research methods (2. útg). Oxford: Oxford University Press.

Ciulla, J. (2005). Integrating leadership with ethics: Is good leadership contrary to human nature? Í J. Doh, S. Stumpf, og F. Springer (Ritstj.), Handbook on responsible leadership and

governance in global business. 159-179. London: Edward Elgar Publishing.

Coleman, M. og Early, P. (2005). Leadership and management in education cultures, change an context. Oxford: Oxford Univeristy Press.

Daft, R.L. (1998). Leadership Theory and Practice. USA: The Dryden Press.

Dornyei, Z. (2007). Research methods in applied linguistics. New York: Oxford University Press.

Dögg Gunnarsdóttir. (2007). „Íslenski stjórnunarstílinn.“ Frjáls verslun, 9 tbl..

Eiríkur Bergmann. (2014). Boom, Bust and Recovery. Palgrave Macmilllan

Fenzl, T. og Pelzmann, L. (2012). Psychological and Social Forces Behind Aggregate Financial Market Behavior. Journal of Behavioral Finance, 13 (1), 56-65.

Ferðamálastofa. (2019). 2,2 milljónir erlendra farpega 2017. Sótt af https://www.ferdamalastofa.is/is/um-ferdamalastofu/frettir/22-milljonir-erlendra-farthega-2017

Gallup. (2018). Landhelgisgæslan nýtur mest trausts almennings. Sótt af https://www.gallup.is/frettir/landhelgisgaeslan-nytur-mests-trausts-almennings/.

Gephart, R. P. (2004). Qualitative Research and the Academy of Management Journal. Academy of Management Journal, 47 (4), 454-462.

Gill, R. (2000). Discourse analysis. Í M.W. Bauer og Gaskell, G. (ritsj.), Qualitative research with text, image and sound: A practical handbook. London: Sage.

Guðni Tómasson. (2017). Var árið 2007 fullkomið? RÚV. Sótt af https://www.ruv.is/frett/var-arid-2007-fullkomid

Guðrún Finnborg Pórðardóttir og Hrafnhildur Mooney. (2016). Fyrirtækja- og áhættumenning - mikilvægur páttur í starfsemi fyrirtækja á fjármálamarkaði. Sótt af https://www.fme.is/media/utgefid-efni/Fyrirtaekja--ogahaettumenning.pdf

Gunnar Hersveinn. (2013). Djóðgildin 5 árum eftir hrun. Sótt af http://www.thjodgildin.is/thjodgildin-5-arumeftir-hrun/

Gylfi Magnússon. (2006). Ávöxtun íslenskra hlutabréfa á uppgjörstíma. Tímarit um viðskipti og efnahagsmál, 4 (1), 87-113.

Halla Tómasdóttir, Frosti Ólafsson, Ásta Dís Óladóttir, Davíð Porláksson, Davíð Scheving Thorsteinsson. (2007). Iceland's advance: foreign investment 2001-2006 Viðskiptaráð Íslands. ISBN 9789979963592

Haukur Freyr Gylfason, Friðrik H. Jónsson og Haukur C. Benediktsson. (2006). Of öryggi: Aukin áhætta í fjárfestingum. Í Rannsóknir i félagsvísindum VII. Bók viðskipta- og hagfræðideildar, ritstj. Ingjaldur Hannibalsson. Bls. 171-177. Reykjavík: Háskólaútgáfan. 
Haukur Freyr Gylfason, Friðrik H. Jónsson og Haukur C. Benediktsson. (2007). Of öryggi metið út frá öryggisbili. Í Rannsóknir í félagsvísindum VIII. Bók viðskipta- og hagfræðideildar, ritstj. Ingjaldur Hannibalsson. Bls. 217-224. Reykjavík: Háskólaútgáfan.

Ho, P.-H., Huang, C.-W., Lin, C.Y. og Yen, J.-F. (2016). CEO overconfidence and financial crisis: Evidence from bank lending and leverage. Journal of Financial Economics, 120 (1), 194-209.

Hrafnhildur M. Eyjólfsdóttir og Smith, P. (1996). „Icelandic business and management culture.“ International Studies of Management \& Organization, 26 (3), 61-72.

Ingi Rúnar Eðvarðsson og Guðmundur Kristján Óskarsson. (2009). Íslenskir stjórnendur: Einkenni, stjórnunaraðferðir og árangur. Bifröst Journal of Social Science, 3 (1), 45-65.

Jones, G. R. (2013). Organizational Theory, Design and Change. (7. útgáfa). England: Pearson Prentice Hall.

Jóhanna Sigurðardóttir. (2009). Efnahagshrun og endurreisn, munnleg skýrsla forsætisráðherra, ein umræða. Sótt af https://www.althingi.is/skodalid.php?lthing=138\&lidur=lid20091006T133126

Kristín Loftsdóttir og Helga Björnsdóttir. (2015). „Áhættusækni í útrásargleði: Karlar og konur í bönkum og fjármálafyrirtækjum“. Tímarit um stjórnmál \& stjórnsýslu, 2 (11), 231-246.

Magnús Sveinn Helgason. (2010). Íslenskt viðskiptalíf-breytingar og samspil við fjármálakerfið. Viðauki 5 í Skýrslu rannsóknarnefndar Alpingis um aðdraganda og orsakir falls bankanna 2008. Reykjavík: Rannsóknarnefnd Alpingis.

Magnússon, G., Minelgaite, I., Kristjánsdóttir, E.S. og Christiansen, P.H. (2018). Here to stay? The rapid evolution of the temporary staffing market in Iceland. Tímarit um stjórnmál og stjórnsýslu, 2 (14), 135-158. https:// doi.org/10.13177/irpa.a.2018.14.2.7

Margrét V. Bjarnadóttir og Guðmundur Axel Hansen. (2010). Rannsókn á krosseignatengslum og útlánum bankanna til tengdra aðila. Viðauki 2 í Skýrslu rannsóknarnefndar Alpingis um aðdraganda og orsakir falls bankanna 2008. Reykjavík: Rannsóknarnefnd Alpingis.

Meyer, D. J. og Meyer, J. (2005). Relative Risk Aversion: What Do We Know? Journal of Risk and Uncertainty, 31 (3), 243.

Minsky, H. (1992). The Financial Instability Hypothesis. Working Paper No. 74. The Jerome Levy Economics Institute of Bard College. http://www.levy.org/pubs/wp74.pdf.

Mintzberg, H. og Gosling, J. (2002). „Educating managers beyond borders.“ Academy of Management Learning and Education, 1 (1), 64-75.

Mixa, W.M. og Vaiman, V. (2015). Individualistic vikings: Culture, economics and Iceland. Tímarit um stjórnmál og stjórnsýslu, 11 (2), 355-374.

Northouse, P. (2016). Leadership: Theory and practice. Thousand Oaks: SAGE.

Páll Hreinsson, Sigríður Benediktsdóttir og Tryggvi Gunnarsson. (2010). Aðdragandi og orsakir falls íslensku bankanna 2008 og tengdir atburðir. Rannsóknarnefnd Alpingis. Reykjavík.

Sanders, Wm. G. og Hambruck, D. C. (2007). Swinging For the Fences: The Effects of CEO Stock Options on Company Risk-Taking and Performance. Academy of Management Journal, 50 (5), 1055-1078.

Seðlabanki İslands. (2006). The economy of Iceland 2006. Sótt af https://www.cb.is/library/Skraarsafn/Economy-of-Iceland/EOI\%20September\%202006.pdf

Seðlabanki Íslands. (2018). Fjármálastöđugleiki. 2018 (1).

Shiller, R.J. (2017). Narrative Economics. Amerian Economic Review, 107 (4), 967-1004.

Shiller, R.J. (2019). Narrative Economics. How Stories Go Viral and Drive Major Economic Events. Princeton: Princeton University Press.

Sigrún Davíðsdóttir. (2006). Íslensk fyrirtæki á Norðurlöndunum: aðferðir og orðspor. Skýrsla á vegum Útflutningsráðs Íslands.

Sigurður Már Jónsson. (2014, 23. nóvember). Gróska í nýsköpun í sjávarútvegi, MBL. Sótt af https://www.mbl. is/vidskipti/pistlar/sigurdurmar/1517996/

Sigurjonsson, T.O. og Mixa, M.W. (2011). Learning From the "Worst Behaved": Iceland's Financial Crisis and the Nordic Comparison. Thunderbird International Business Review, 53 (2). DOI: 10.1002/tie

Sigurjonsson, T.O. (2010) Privatization and Deregulation: A Chronology of Events. In R.Z. Aliber and G. Zoega (Eds.), Preludes to the Icelandic Financial Crisis. London, UK (26-40), Palgrave Macmillan.

Sigurlína Davíðsdóttir .(2003). Eigindlegar eða megindlegar rannsóknaraðferðir? Í Sigríður Halldórsdóttir og Kristján Kristjánsson (ritstj.), Handbók i aðferðafræði og rannsóknum í heilbrigðisvísindum (bls.219-236). Akureyri: Háskólinn á Akureyri.

Stefán Ólafsson. (2016). Hrunið skýrt: Sjónarhorn klassískra kenninga um fjármálakreppur. Tímarit um stjórnmál \& stjórnsýslu, 1 (12), 101-126.

Stogdill, R. M. (1948). Personal factors associated with leadership; a survey of the literature. Journal of Applied Psychology, 25 (3).

Stogdill, R.M. (1974). Handbook of Leadership: A survey of theory and research. New York: Free Press.

Yukl, G. A. (2013). Leadership in Organizations (8. útg). New Jersey: Pearson Education Inc.

Wong, A. og Carducci, B.J. (1991). Sensation Seeking and Financial Risk Taking in Everyday Money Matters. Journal of Business and Psychology, 5 (4), 525-530. https://doi.org/10.1007/BF01014500 
36 I Tímarit um viðskipti og efnahagsmál

Pingskjal 959. (2012). Tillaga til pingsályktunar um staðfestingu ákvörðunar sameiginlegu EES-nefndarinnar nr. 19/2012 um breytingu á IX. Viðauka (Fjármálapjónusta) við EES-samninginn. Sótt af https://www.althingi.is/altext/140/s/0959.html

Pjóðfundur 2009 (ed). (2009). Pjóðfundur stefnumót við framtíðina. Sótt af http://www.thjodfundur2009.is/ Porkell Sigurlaugsson. (2009). Ný framtíðarsýn. Reykjavík: Bókafélagið Ugla ehf. 